\title{
SOCIÁLNÍ KONTEXT SLOVANSKO-NĚMECKÉHO JAZYKOVÉHO KONTAKTU. SEVEROVÝCHODNÍ BAVORSKO A CHEBSKO V RANÉM STŘEDOVĚKU
}

\author{
TOMÁŠ KLÍR
}

\begin{abstract}
Abstrakt: Prostorové rozloženi slovanských hydronym a mistních jmen v jednotlivých částech severovýchodního Bavorska a Chebska je nápadně rozdilné. Zatímco hydronyma slovanského původu lze doložit jen v malé části regionu, slovanská mistni jména téměr všude, i když někde jen mozaikovitě. Př́činou jsou diametrálně odlišné sociálni procesy, které stály v pozadi jazykového kontaktu v obdobi 8./9.-12./13. století. Někde k jazykovému kontaktu docházelo $v$ di̊sledku pronikáni sociálně minoritni slovanštiny, jinde $v$ důsledku šíreni sociálně dominantní němčiny. Podobnou výpověd’ nese i prostorové rozšírení různých kategorií a typů jmen německých. Díky různé hierarchii hydronym lze zároven̆ alespon̆ rámcově určit, kde, kdy a v jakých částech společnosti byl realizován německý, nebo naopak slovanský jazyk, popr. oba součas-

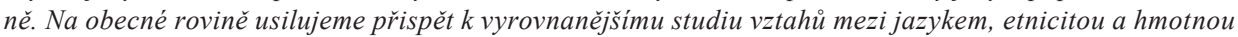
kulturou, a k poznáni procesů kulturní změny a migrace.
\end{abstract}

Klíčová slova: jazykový kontakt - onomastika - 750-1150-Bavorsko-Chebsko.

The Social Context of the Slavic-German Language Contact. North-eastern Bavaria and the Cheb Region in the Early Middle Ages

\begin{abstract}
The spatial distribution of Slavic hydronyms and toponyms in the individual parts of northeastern Bavaria and the Cheb region varies considerably. While hydronyms of the Slavic origin are only confirmed on a small proportion of the region, Slavic toponyms are widespread, though in some areas in a mosaic-like pattern. This was due to extremely diverse social processes that were behind the language contact between the $8 \mathrm{th} / 9$ th century and the 12th/13th century. In some areas the language contact was the consequence of the penetration of the socially minor Slavic language, in other areas it resulted from the spreading of the socially dominant German language. A similar picture is provided by the spatial distribution of various categories and types of German names. Owing to a different hierarchy of hydronyms, it is also possible to determine, at least roughly, where, when and by which social strata the German or Slavic language was spoken, or both. At a more general level, the paper seeks to contribute to a more balanced study of the connections between language, ethnicity and material culture, as well as to the identification of the processes of cultural change and migration.
\end{abstract}

Key words: language contact - onomastics - 750-1150-Bavaria - Cheb region.

\section{1. Úvod}

Toponymické soustavy uchované v jazykově kontaktních oblastech jsou extrémně zajímavým předmětem analýzy, nebot' osvětlují ty aspekty minulé skutečnosti, do nichž jiné prameny obvykle nahlédnout nedokáží. Jejich informační potenciál plyne z obecného faktu, že každý výsledek jazykového kontaktu je dán nejen jazykovými, ale také sociálními faktory. Mimo jiné sociálním kontextem jazykového kontaktu, nerovnoměrnou distribucí jazykového repertoáru a jeho různou realizací např́íč společností. Je samozřejmé, že takové studium přesahuje rámec jednotlivých akademicky institucializovaných oborů, jakými jsou na jedné straně sociolingvistika, kontaktová lingvistika nebo onomastika a na druhé archeologie a tradiční historické vědy.

V rámci dlouhého geografického pásu táhnoucího se od Jutského poloostrova po Alpy, kde se v raném středověku prolínala německá a slovanská nářečí, je jednou z problémově nejzajímavějších oblastí dnešní severovýchodní Bavorsko a Chebsko (Schwarz E. 1960; Eichler et al. 2001; 2006; Klír 2015; v tisku). Jedinečná pramenná evidence zde pro raný stř̌edověk dovoluje sledovat vztah mezi různým užíváním jazyka, konstruováním etnické identity a hmotnou kulturou. Předkládaný př́ispěvek neusiluje řešit tuto komplexní problematiku jako celek, ale soustř́edí se na jazykové aspekty. Hlavní otázka zní, jaké sociální procesy vedly ke slovansko-německému jazykovému kontaktu. S tím úzce souvisí problém, v jakém období, v jakých oblastech a v jaké 
části společnosti byl zastoupen slovanský nebo německý jazyk, popř. oba jazyky zároveň. Při řešení využijeme toho, že raný stř̌edověk byl obdobím sídelního postupu a že časově a sociálně variabilní jazykové poměry se otiskly do podoby toponymických soustav, které jsou v jednotlivých částech severovýchodního Bavorska a Chebska nápadně rozdílné.

Příspěvek je rozdělen do dvou částí. V prvé představujeme základní teoretický rámec založený na vybraných modelech současné onomastiky a sociolingvistiky (kapitoly 2-5). Druhá část obsahuje přehled, analýzu, srovnání a interpretaci jednotlivých kategorií toponym v severovýchodním Bavorsku a na Chebsku (kapitoly 6-8).

\section{TEORETICKÁ VÝCHODISKA}

\section{Obecná východiska}

\subsection{Sledovaná oblast}

Z hlediska historického a jazykového vývoje není sledovaná oblast jednotná, ale skládá se ze tří historicky, nářečně i geograficky rozdílných částí (tab. 1,2). Zaprvé z francké části, konkrétně východních Frank, zadruhé z bavorské části, především Horní Falce a zatřetí z tzv. historického Chebska. Z geografického pohledu je severovýchodní Bavorsko ohraničeno na severu horským pásem Durynský les - Francký les - Smrčiny, na východě Hornofalckým lesem a Šumavou, na jihu řekami Dunajem a Altmühlem a na západě linií vrchovin Franckého triasu. Východní Franky jsou od Horní Falce odděleny horskou bariérou Francké Alby. Franky jsou z velké části odvodňovány řekou Mohanem, pouze severovýchodní část patří do povodí Sály. Horní Falc zase řekou Nábou. Historické Chebsko zahrnovalo rozvodí Mohanu, Náby, Ohře a Sály (obr. 1).

\begin{tabular}{|c|c|c|c|}
\hline Současné německé nářeči & Historická část & Prostorová specifikace & Literatura (jazykové poměry) \\
\hline Ostfränkisch & Východní Franky & $\begin{array}{c}\text { Horní Franky }\left(7231 \mathrm{~km}^{2}\right) \text {; většina Středních } \\
\text { Frank }\left(7244 \mathrm{~km}^{2}\right) \text {; východní okraj } \\
\text { Dolních Frank }\end{array}$ & Steger 1968; Rowley 1997 \\
\hline $\begin{array}{l}\text { Nordbairisch*, } \\
\text { Nord-mittelbairisch** }\end{array}$ & $\begin{array}{l}\text { Horní Falc, Chebsko, } \\
\text { část Dolního Bavorska }\end{array}$ & $\begin{array}{c}\text { Horní Falc }\left(9691 \mathrm{~km}^{2}\right) \text {; z Dolního } \\
\text { Bavorska Landkreis Kötzing a Viehtach } \\
\left.\text { (ca } 2000 \mathrm{~km}^{2}\right) \text {; okres Cheb v ČR }\left(1045 \mathrm{~km}^{2}\right)\end{array}$ & $\begin{array}{c}\text { Kranzmayer 1956; Harnisch } \\
\text { 1983; Rowley } 1997\end{array}$ \\
\hline
\end{tabular}

* V české části tzv. historického Chebska pouze do roku 1945.

** Vládní okresy Roding, Cham, Kötzing, Viehtach (před reformou 1972).

Tab. 1. Německá nářečí ve sledované oblasti.

Tab. 1. Deutsche Dialekte im untersuchten Gebiet.

\begin{tabular}{|c|c|}
\hline Vývojový stupeň němčiny & Chronologie \\
\hline Germánština & do $700 / 750$ \\
\hline Stará horní němčina & $750-1050$ \\
\hline Střední horní němčina & $1050-1350$ \\
\hline Raná nová horní němčina & $1350-1650$ \\
\hline
\end{tabular}

Tab. 2. Orientační přehled vývojových stupňů němčiny ve středověku (srov. Roelcke 1995).

Tab. 2. Orientierungsübersicht der Entwicklungsstufen des Deutschen im Mittelalter (vgl. Roelcke 1995).

Historický vývoj jednotlivých částí severovýchodního Bavorska a Chebska v raném středověku je předmětem živých diskusí. To je dáno nejen značnou torzovitostí pramenné základny a geografickou roztř́šstěností, ale také velmi širokým časovým rozpětím, které zahrnuje diametrálně odlišné společnosti. V dosavadní literatuře přitom jednoznačně dominuje tradiční „,koloniální“ perspektiva, která vývoj a kulturní změnu vnímá jako vyzařování inovace z dominantního centra na pasivní periferii. Nezbytnou součástí tohoto konceptu je vize o teritoriálním posunu a expanzi, nárazníkovém pásmu, popř. polopropustné hranici s jistou mírou kontroly sociálních 


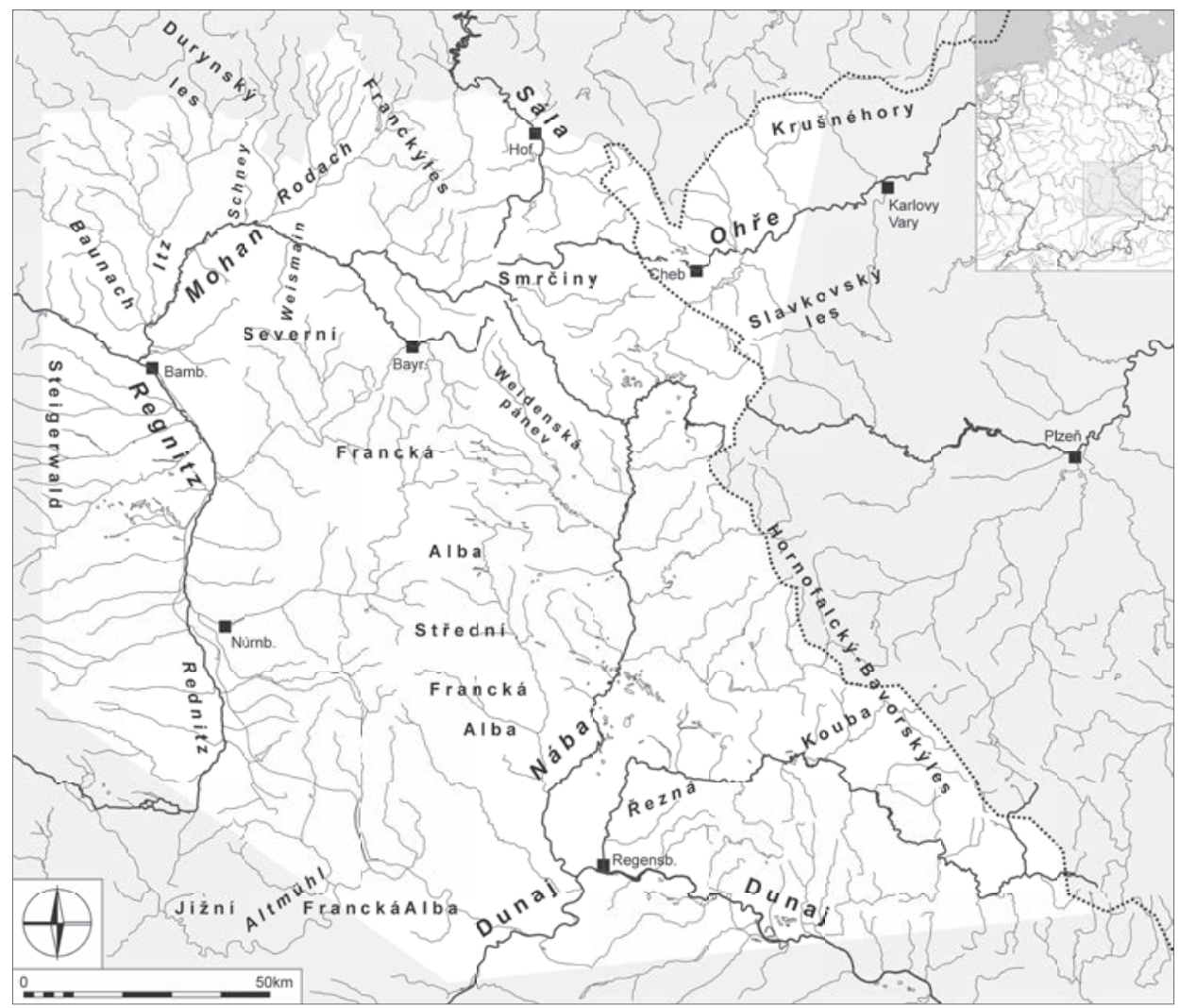

Obr. 1. Severovýchodní Bavorsko a Chebsko. Kostra vodní sítě (kurzívou) a základní geomorfologické jednotky zmiňované v textu. Orientační body: Nürnb. = Norimberk, Bamb. = Bamberk, Bayr. $=$ Bayreuth, Regensb. $=$ Řezno.

Abb. 1. Nordostbayern und Egerland. Wasserlaufsystem (kursiv) und im Text erwähnte geomorphologische Grundeinheiten. Orientierungspunkte: Nürnb. = Nürnberg, Bamb. = Bamberg, Bayr. = Bayreuth, Regensb. $=$ Regensburg.

interakcí, informační výměny a pohybu zboží. Toto paradigma je dnes ve své vyhraněné podobě neudržitelné a i v případě východních částí francké ř́iše vše směřuje $\mathrm{k}$ jeho revizi (srov. př́ispěvky v Curta ed. 2005; Pohl-Reimitz edd. 2000).

Podle tradičního výkladu měla být základní historická trajektorie severovýchodního Bavorska do velké míry určena tím, že bylo otevřeno do středního Porýní a jeho jednotlivé části tvořily východní okraj francké, později německé říše. Od 6.-7. století je na základě různých druhů pramenů postulována představa o zprvu geograficky fázovité, přerušované a pomalé integraci celé oblasti do říšských mocenských, ekonomických a církevních struktur, která byla dovršena vznikem bamberského biskupství (1007) a kolonizací v 11.-12. století. Pro 6.-9. století se hovoří přímo o tzv. procesu „frankizace“, v jehož rámci byla lokální populace postupně ovládnuta franckými sociálními elitami, které byly zároveň organizátory dalšího sídelního postupu. Na tomto místě se problematice východních okrajů francké říše a jejich sídelně-historickému vývoji nelze detailněji věnovat; odkázat lze na bilanční sborníky a studie (Störmer 1999, 42-100; Schmale-Störmer 1997; Merz-Schuh edd. 2004; Bergmann et al. edd. 2007; Häusler 2004; Stieldorf 2012; pro většinu historických vládních okresů jsou k dispozici jednotlivé svazky vycházející od roku 1950 v rámci projektu „Historisches Atlas von Bayern“). Stranou musíme ponechat také přehled o sídelním vývoji, jak ho zprostředkovávají archeologické nálezy (zejména Haberstroh J. 2000; Ettel 2001; Pöllath 2002; Losert 1993; Schwarz K. 1984). 


\subsection{Perioda jazykového kontaktu}

Onomastické prameny dokládají jazykový slovansko-německý kontakt v severovýchodním Bavorsku relativně pozdě. První slovanská toponyma se v písemných pramenech objevují až ve druhé třetině 9 . století. Na základě hláskových interferenčních jevů je integrace různých slovanských jmen do němčiny datována do širokého rozmezí 9.-12. století, pouze jeden případ by mohl být starší. Pokud jde o horní časovou hranici, pak je podstatné, že ve všech regionech severovýchodního Bavorska, kde se slovanská vlastní jména vyskytují, nechybí doklady jejich poměrně pozdní integrace do němčiny, tj. ještě po polovině 11. století (Eichler et al. 2001; 2006; Fastnacht 2007, 70*-90*; George 2008; Schwarz E. 1960, 176-301). Zdá se, že slovanský jazyk zde ze všech jazykových domén zmizel někdy v období od druhé poloviny 11. do 12. století. Poměrně náhlý zánik slovanského jazyka v severovýchodním Bavorsku lze vysvětlit souhrou více faktorů, od radikální proměny sociosymbolických aspektů jazyka až po rozpad tradičních rolnických komunit. Nicméně okrajové užívání slovanského jazyka ještě ve 13. století není teoreticky vyloučeno, je však pouhou spekulací. Jazykové poměry v české části tzv. historického Chebska se vyvíjely mírně odlišně, slovanský jazyk zde byl aktivní až do poloviny 13. století (Fischer 1940).

\subsection{Etnicita, jazyk a materiální kultura}

Následující kapitoly jsou věnovány jediné skupině pramenů - toponymům. Pokud by jejich výpověd’ měla být konfrontována s písemnými zmínkami o etnických Slovanech („Sclavi“/,Winidi“), s etnogenními sídlištními jmény typu/-winden-/ nebo s archeologickou evidencí, bylo by nutné zaujmout pozici ke vztahu jazyka, etnicity a materiální kultury (k písemným zmínkám přehledně např. Störmer 1999, 174-288; Herrmann 1965; ke jménům s /-winden-/ souhrnně Reitzenstein 1991/92). To je úkolem jiné připravované studie, a na tomto místě proto stačí uvést, že „Sclavi““,Winidi“, známí z písemných pramenů a někdy spojovaní i s určitými prvky v hmotné kultuře, byli externě konstruovanou etnickou skupinou, která se nemusela překrývat ani s kolektivními identitami pomohanské, popř. ponábské populace, a již vůbec ne s obyvatelstvem jazykově dominantním ve slovanštině.

V každém případě právě v nezávislé rekonstrukci jazykových poměrů spatřujeme první a nezbytný krok, jak systematicky řešit otázku, do jaké míry byl jazyk využíván pro konstrukci etnické identity v raně středověkém severovýchodním Bavorsku a jak mu z tohoto hlediska konkurovaly neverbální emblematické styly (souhrnně např. Brather 2004, 39-44, 188-201; 2006, 64-67; Curta 2008; Fishman-García edd. 2010; Pohl-Zeller edd. 2012).

\subsection{Terminologická poznámka}

Jestliže užíváme zjednodušený termín slovanský mluvčí, je jím myšlena osoba jazykově dominantní ve slovanském jazyce. To znamená, že slovanský mluvčí sice může rozumět a užívat více jazyků, může být multilingvní, ale ve slovanském je nejvíce zdatný. Jazykovou dominanci nelze zaměňovat se sociální dominancí.

Na území dnešního severovýchodního Bavorska se v současnosti nachází výlučně německá toponyma. Některá z nich však v sobě nesou slovanské jazykové prvky, neboli mají alespoň částečně slovanskou etymologii. Tato jména dále nazýváme zjednodušeně jako slovanská, a užíváme tedy pojmy jako slovanská hydronyma, slovanská místní jména atd. Podobně bychom mohli definovat i jména označovaná zde jako germánská a časně německá. 


\section{Sociální kontext jazykového kontaktu}

\subsection{Tradiční historická debata}

Historiografie diskutuje otázku, zda k jazykovému kontaktu v severovýchodním Bavorsku docházelo $\mathrm{v}$ důsledku migrace slovansky hovořících komunit do regionů osídlených populací jazykově germánsko-německou, nebo naopak v důsledku expanze franckých a říšských mocenských struktur, která byla do různé míry doprovázena migrací německých mluvčích na území obývané slovansky hovořící populací. V prvém případě se hovoří o tzv. imigrační teorii, ve druhém o tzv. kolonizační teorii (klasicky: Bachmann 1926; Guttenberg 1927; Schwarz E. 1960, 344-384). Tutéž názorovou polarizaci lze sledovat také při výkladu chebské situace (Klír 2015, 176-178). Jednotlivé výklady si v různých podobách dodnes konkurují, ani jeden z nich nebyl definitivně potvrzen či vyloučen (nověji např. Bergmann et al. edd. 2007; Fastnacht 2007, 70-81*; Endres 2003; Schuh 2004; Haberstroh J. 2004, 16-17; Häusler 2004, 74-75; Pöllath 2002, 12-55; Giesler 1997, 206-210).

Dosavadní historická debata více či méně předpokládala jednotu jazyka a etnicity, tedy etnojazykovou identitu, a jazykový kontakt byl proto vnímán zároveň jako etnický kontakt. Z toho důvodu byly francké zprávy o etnických Slovanech a etnogenní místní jména typu /-winden-/ interpretovány jako doklad slovanského jazyka, a naopak v toponymech se slovanskými jazykovými prvky byli viděni etničtí Slované. Domníváme se, že etnicitu a jazyk je třeba z praktických důvodů rozpojit a každou z těchto kategorií analyzovat samostatně. Podstatné přitom je, že poměrně nepřehlednou debatu o průběhu slovansko-německého jazykového kontaktu v severovýchodním Bavorsku a na Chebsku lze transformovat do modelových sociolingvistických kategorií.

\subsection{Sociolingvistická klasifikace}

Pokud jde o jazykový kontakt, historická debata má přímou paralelu v sociolingvistické modelové klasifikaci sociálních procesů, které vedly k jazykovému kontaktu a determinovaly jeho výsledek (např. Sankoff 2006). Na teoretické rovině je realita zjednodušována a rozlišovány jsou dva základní typy takových sociálních procesů. První typ může být nazýván podmanění („conquest“), druhý přistěhovalectví (,immigration“).

\section{„Immigration“}

Tento sociální proces je vždy vyvolán migrací nebo organizovaným transferem sociálně minoritní populace, která se různými způsoby začleňuje do populace sociálně dominantní. Velmi často dochází k poměrně rychlé jazykové asimilaci a k jen malému ovlivnění obou kontaktních jazyků (Sankoff 2006, 642). Sociální proces „immigration“ nemusí zanechat žádnou stopu v toponymické soustavě sociálně dominantního jazyka. Výjimkou jsou situace, kdy nově příchozí jazykově minoritní populace vstupují do neosídlených enkláv, kde se mohou vytvářet poměrně stabilní jazykové ostrovy s primární imigrační toponymií, která je teprve později integrována do sociálně dominantního jazyka.

\section{„Conquest"}

Lokální, autochtonní jazyková skupina je integrována jinou, sociálně dominantní jazykovou skupinou. Do procesu ,podmaněni““ lze zahrnout celou škálu sociálních procesů. Na jedné straně může jít o skutečné podmanění jedné jazykové populace druhou, doprovázené navíc migrací elit a venkovské populace. $\mathrm{V}$ tom případě obvykle následuje rychlé proniknutí sociálně dominantního a prestižnějšího jazyka do všech typů jazykových interakcí. Na druhé straně sem patří takové situace, jako je poměrně rovnocenné začlenění určitého teritoria do většího politického celku provázené bilingvitou pouze jedné z jazykových domén. 
Délka bilingvního období v rámci „conquest“ kontextu závisí na mnoha sociálních faktorech. Např́íklad při přibližné sociální a kulturní rovnosti obou jazyků se může utvořit poměrně stabilní a dlouhodobá dvojjazyčná situace (tj. bilingvita bez diglosie; Sankoff 2006, 642). Ale pokud je jazyk aktivním nástrojem, kterým je konstruována sociální realita (jazyk je nositelem významných sociosymbolických funkcí), případně předpokladem sociální mobility, může velmi rychle dojít $\mathrm{k}$ jazykové změně a vymření sociálně minoritního a méně prestižního jazyka (Romaine 2010). Podstatné je, že sociální proces „conquest“ obvykle zanechává výraznou stopu v onymické soustavě sociálně dominantního jazyka. To je dáno tím, že onymická soustava sociálně dominantního jazyka vzniká na základě onymické soustavy sociálně minoritního jazyka.

Tuto duální sociolingvistickou typologii považujeme za efektivní poznávací nástroj. Nicméně toponyma $\mathrm{v}$ kontaktních oblastech není možné interpretovat pouze v rámci binárního konceptu „imigrace“ versus „,conquest“, jak se o to snažila starší historiografie, nebot’ rozdíly v podobě dodnes dochovaných toponymických soustav nejsou př́mým odrazem minulých jazykových poměrů, ale plošným součtem velkého množství sociálních a jazykových faktorů, mezi jiným sociálně rozdílnou realizaci slovanského a německého jazyka. Neboli jedno konkrétní toponymum nás neinformuje o jazykových poměrech ve společnosti jako celku, ale referuje jen o některé její části. $\mathrm{Z}$ toho důvodu je třeba pokročit hlouběji a pokusit se formulovat ideální kritéria, pomocí kterých by bylo možno identifikovat sociální kontext jazykového kontaktu pro jednotlivá společenská patra (kap. 5). Ještě předtím je však třeba alespoň stručně zmínit onomastické modely užívané pro studium jazykového kontaktu, jakož i další základní kategorie užívané sociolingvistikou (kap. 4).

\section{Kontaktová onomastika a sociolingvistické kategorie}

Moderní evropská onomastika vypracovala několik v principu velmi podobných modelů, které popisují převzetí vlastních jmen z jednoho jazyka do druhého. Nejvyspělejším z nich je model toponymické integrace, formulovaný „lipskou“ onomastickou pracovní skupinou (Hengst 1996; Wulf 2000; literaturu shrnuje Bily 2000, 16-21; 2000a). Převzetí místních jmen z jednoho jazykového systému do druhého je v „lipském“ modelu vnímáno jako proces zahrnující řadu dílčích jevů, které jsou oproti realitě zjednodušovány a teoreticky seřazeny do tří oddělených a na sebe navazujících fází jazykového kontaktu (tab. 3).

\begin{tabular}{|c|c|}
\hline Fáze & Charakteristika \\
\hline 1. Předkontaktní fáze & $\begin{array}{l}\text { Oba jazyky existují vedle sebe, ale ještě nedochází k přímému kontaktu mezi jejich nositeli. } \\
\text { Místní jména se vyvíjí v rámci daného jazykového systému, v rámci jeho hláskoslovi } \\
\text { a slovotvorby. }\end{array}$ \\
\hline $\begin{array}{c}\text { 2. Kontaktní fáze } \\
\text { (období bilingvity a diglosie) }\end{array}$ & $\begin{array}{l}\text { Zahrnuje proces převzetí jmen a jejich začlenění do integrujícího jazyka. Jedná se o období } \\
\text { jazykové souběžnosti německého a slovanského jazyka. Během této fáze mohou působit } \\
\text { protichůdné tendence, až je konečně dosažen foneticky, graficky i morfematicky stabilní } \\
\text { tvar jména. } \\
\text { Kontaktní fázi je možno modelově rozdělit na dvě podfáze. Jednak na vlastní přenos (IIa), } \\
\text { a pak na následné přizpůsobení jména novému jazyku (IIb). Podstatou první podfáze je } \\
\text { hlásková adaptace, podstatou druhé pak přizpůsobení v ostatních strukturálně jazykových } \\
\text { rovinách (morfologická a sémantická adaptace). Pokud bychom modelové jevy nedávali př́mo } \\
\text { do návazného sledu, místo podfází by bylo možno hovořit o jazykových operacích. Konkrétni } \\
\text { př́klady srov. níže u modelu jmenných párů. }\end{array}$ \\
\hline 3. Postkontaktní fáze & $\begin{array}{l}\text { Popisuje vývoj převzatého jména v integrujícím jazyku bez dalšího kontaktu s výchozím ja- } \\
\text { zykem. Během této fáze se místní jméno mění především v důsledku interakce apelativní a } \\
\text { propriální sféry jazyka. Charakteristická je také snaha zakotvit ho v cílovém jazyce - např. } \\
\text { sekundární sémantická motivace. }\end{array}$ \\
\hline
\end{tabular}

Tab. 3. Fáze jazykového kontaktu v ,lipském“ modelu toponymické integrace.

Tab. 3. Sprachkontaktphasen im ,Leipziger“ Integrationsmodell.

S modelem toponymické integrace úzce souvisí model jmenných párů, který popisuje průběh a výsledek toponymické integrace a se kterým operovala již starší kontaktová onomastika. Nověji jej upravila i „lipská“ skupina (Hengst 1996, 1009-1010; shrnuje Besse 2000). Tento 
model předpokládá, že v období jazykového kontaktu se vytváří paralelní onymické soustavy, přičemž v ideálním př́ípadě by každý pojmenovaný objekt měl mít zvláštní jméno v každém z obou jazyků. Tato jména pak vytváŕí tzv. jmenný pár. V zásadě si lze představit čtyři typy jmenných párů (tab. 4).

\begin{tabular}{|c|c|}
\hline Typ páru & Charakteristika a přiklady \\
\hline 1. Hláskově vázané & $\begin{array}{l}\text { Jedno místní jméno je primární, druhé z něho vychází. Primární jméno je integrováno } \\
\text { v rovině jednotlivých fonémů, popř. morfémů. Podle tvaru lze rozlišit německá místní } \\
\text { jména členěná a nečleněná. V prvém př́padě se uplatnila pouze fonetická adaptace (např. } \\
\text { hydronymum slovanské *Kozina - německé Kössein). Ve druhém případě již aktivně } \\
\text { působily slovotvorné prostředky integrujícího jazyka, došlo tedy také k částečné morfémové } \\
\text { adaptaci (např. hydronyma slovanské * } L^{\prime} \text { ubina - německé Laibach). }\end{array}$ \\
\hline 2. Formálně vázané & $\begin{array}{l}\text { Lexém slovanského jména sémanticky odpovídá určujícímu nebo základnímu slovu } \\
\text { německého kompozita. Např. hydronyma slovanské *Dobra - časně německé *Dobraha } \\
(>\text { dnešni Dobrach). }\end{array}$ \\
\hline 3. Sémanticky vázané & $\begin{array}{l}\text { Lexémy místního jména mají v obou jazycích shodný význam. Bez znalosti historických } \\
\text { souvislostí nelze spolehlivě určit, které z těchto místních jmen je primární a které } \\
\text { sekundární. Jména mohou být vytvořená i současně. Př.: hydronyma slovanské *Bělica - } \\
\text { německé Weißenbach. }\end{array}$ \\
\hline 4. Volné („loan creation“) & $\begin{array}{l}\text { Členy jmenného páru nejsou provázány na žádné z jazykových rovin, ale spojuje je pouze } \\
\text { objekt, který označuji. Např. hydronyma české Račí potok-německé Selb. }\end{array}$ \\
\hline
\end{tabular}

Tab. 4. Typy jmenných párů (příklady Eichler 1993; Hengst 1999, 41-49).

Tab. 4. Namenpaartypen (Beispiele Eichler 1993; Hengst 1999, 41-49).

Podstatné je, že v bilingvním období se členy jmenného páru různým způsobem neustále vzájemně ovlivňují a může vznikat více lokálně, sociálně a chronologicky odlišných variant pojmenování. Se zánikem jednoho jazyka mizí i př́slušná onymická soustava a s ní všechny členy jmenných párů, které ji tvoří. Neboli do jazykově postkontaktní fáze přejdou pouze členy jmenných párů užívané v sociálně dominantním jazyce.

Tradiční onomastika operovala s abstraktní představou, že komunity mluvčích jednotlivých jazyků užívají mezi sebou svá vlastní pojmenování a mluvčí, kteří jsou bilingvní, užívají podle potřeby pojmenování adekvátní pro jednu či druhou jazykovou komunitu. Pod vlivem sociolingvistiky je třeba tuto představu modifikovat v tom smyslu, že bilingvní jedinec uplatňuje toponymum v takové jazykové podobě, která je relevantní pro situačně-institucionální kontext, v němž svou promluvu realizuje (Matras 2010, 66).

Model toponymické integrace a jmenných párů je idealizovaný a plošný, a pro naše potřeby je nutné ho mírně modifikovat pomocí centrálních sociolingvistických konceptů (např. Hickey ed. 2010; Mesthrie ed. 2011; Milroy-Gordon edd. 2003; Chambers-Schilling-Estes edd. 2013, popř. také Thomason-Kaufman 1988; Van Coetsem 1989, 2000). Hlavní ideou je teze, že žádná společnost není homogenní, ale na základě různých aspektů je možno ji rozdělit na mnoho částí, z nichž nejzajímavější jsou pro nás sociální třídy, popřr. ranky dělící populaci podle sociálního statusu, bohatství a moci (např. Guy 2011; Ash 2004). Členové různých sociálních tříd se liší svým jazykovým repertoárem (,sociolektem“). Každý jedinec přitom tento sociálně podmíněný repertoár realizuje vždy v konkrétní jazykové interakci, která se odehrává v určitých situačních a institucionálních kontextech - jazykových doménách (např. Fishman 1972; Deumert 2011). Sociolingvistický koncept sociálních tříd a jazykových domén doplňuje užitečným způsobem teorie personálních/sociálních sítí (např. Milroy L. 2006; Conde-Silvestre-Pérez-Raja 2011). Tato teorie předpokládá, že jedinci jsou začleněni v rozmanitých komunitách, které umožňují efektivní řešení každodenních problémů. Zatímco sociálně třídní pojetí zdůrazňuje ekonomické a sociální postavení každého jedince, koncept personálních sítí cílí na jeho jedinečnou životní zkušenost, aktivity a vazby s okolím. V principu by však mělo platit, že rozdíl je pouze v měřítku našeho pohledu. Tedy každou sociální třídu prostupuje velké množství různých personálních sítí (Guy 2011). Nicméně skutečně silná a komplexní personální sít' je omezena pouze na jednu sociální tř́ídu. Pokud jde o vztah personálních sítí a jazykových domén, pak se obě kategorie prolínají. Personální sítě tak mohou být vnímány jako specifické ,arény“, kde jsou realizovány jazykové interakce (tab. 5; Trudgill 2006). 


\begin{tabular}{|c|c|c|c|c|}
\hline \multirow[b]{2}{*}{ Typ domény } & \multirow[b]{2}{*}{ Jazyková doména } & \multicolumn{3}{|c|}{ Personální sítě } \\
\hline & & rolnické & sociální elity & $\begin{array}{l}\text { agenti dálkových } \\
\text { vztahů }\end{array}$ \\
\hline \multirow{3}{*}{1.} & rodina / domov & - & • & - \\
\hline & sousedství & • & • & - \\
\hline & pracovní aktivity & - & • & - \\
\hline \multirow{2}{*}{2.} & mocenské struktury & - & • & • \\
\hline & církevní instituce, vzdělání & - & $\cdot$ & - \\
\hline 3. & dálkové vztahy (směna, obchod) & - & - & • \\
\hline
\end{tabular}

Tab. 5. Modelové typy personálních sítí a jejich průnik do jazykových domén.

Tab. 5. Modelltypen für Personennetzwerke und ihr Vordringen in Sprachdomänen.

Shrneme-li dosud uvedené, onymické soustavy v jazykově kontaktních oblastech jsou sociálně nevyrovnaným torzem, ve kterém se mísí tvary vybrané z různých jazykových domén, personálních sítí a pocházející z repertoárů členů různých sociálních tříd/ranků. Naším úkolem je tuto soustavu dekódovat a určit, v jakém období, v jaké relativní následnosti a v jakých sociálních třídách/rancích byl zastoupen, a v jakých jazykových doménách a personálních sítích byl realizován slovanský nebo německý jazyk.

\section{Dekódování toponymické soustavy}

\subsection{Obecné poznávací možnosti}

Na teoretické rovině je výchozí situace pro naše poznání poměrně slibná. Využít lze toho, že ne všechna vlastní jména vstupují do všech druhů jazykových interakcí, neboli jednotlivé jazykové domény se liší v zastoupení určitých typů vlastních jmen. Dělicí linie přitom neprobíhá podle tradičních onomastických kategorií vlastních jmen (oikonyma, anoikonyma včetně hydronym, antroponyma), ale např́č těmito kategoriemi. Klíčová je hierarchie vlastního jména určená sociálním a geografickým rozsahem personální sítě, která ho používá. Jména nejnižší hierarchie jsou užívána jen lokální rolnickou komunitou, jména nejvyšší hierarchie naopak vstupují do komunikace v rámci personální sítě „dálkové vztahy“. Pokud se sociální tř́ídy/ranky a personální sítě liší v jazykovém repertoáru, mělo by se to odrazit i v onymické soustavě. Např́klad hydronymum si může uchovat germánsko-německou jazykovou kontinuitu i v oblasti, kde je venkovské osídlení jazykově slovanské. Nositelem této jazykové kontinuity totiž mohou být agenti „dálkových vztahư‘, realizující hydronymum v př́íslušné jazykové doméně. Jako další prŕklad lze uvést, že i v prostř́edí striktně německé názvotvorby se může slovanský jazyk projevit, a to průnikem slovanských osobních jmen do německých místních jmen a dále v důsledku transonymizace původně slovanských pomístních jmen. ${ }^{1}$

Druhou poznávací možnost otevírá určení relativního chronologického vztahu jednotlivých jazyků a různých onymických kategorií, tedy určení, která „,jazyková vrstva“ je starší a která mladší, popř. zda jsou současné. Datovací postupy patří mezi tradičně silná pole historické jazykovědy a onomastiky. Chronologické určení vzniku jména využívá toho, že jazyk není statický, ale stále se mění ve všech svých hlavních strukturálních rovinách: lexikální, slovotvorné a hláskové. Onomastika tak nabízí řadu sice komplikovaných, ale logických postupů, jejichž základem je model potenciálních interferenčních vztahů, zejména na hláskové rovině. V ideálním případě lze zjistit počátek a konec jazykového kontaktu (kap. 2.2).

Zařadit určitý tvar vlastního jména do adekvátní jazykové domény a personální sítě umožňuje rovněž znalost rozsahu a charakteru osídlení. Pokud na nějakém teritoriu chybí pro určitou periodu přímé doklady trvalých sídelních aktivit, a onomastika tam přesto přesvědčivě dokládá

1 Při transonymizaci se mění pouze kategorie vlastního jména, nikoliv jeho podoba. Dochází k přenosu místní jméno $\leftrightarrow$ jméno vodního toku $\leftrightarrow$ pomístní (trat'ové) jméno. Srov. Čornejová 2009, 38-39; Šrámek 1999, 43, 55-56. 
časově příslušná toponyma, můžeme hypoteticky uvažovat o tom, že taková toponyma byla realizována v jazykové doméně „dálkové vztahy“, popř. ,mocenské struktury“.

\subsection{Hydronyma}

Specifickou otázku, jakou je určení primárního jazyka v určitém teritoriu, může efektivně zodpovědět analýza hydronym. Ta mají - oproti většině jiných kategorií vlastních jmen - několik významných poznávacích výhod.

Zaprvé množství vodních toků je limitováno. Pokud je hydronymie určité oblasti v jednom jazyce již jednou vytvořena, mají imigrační komunity jen omezené možnosti, jak aktivovat svou názvotvorbu v této onymické kategorii. Ve většině případů pouze přejímají starší jména a adaptují je pro svůj jazyk na hláskové, popř. morfologické rovině. Přejmenování vodního toku není vyloučeno, ale je spíše výjimečné, nebot' by narušilo primární komunikační a identifikační funkci vlastních jmen. Samozřejmě, že toto vše platí především pro kostru vodní sítě a pro významnější hydronyma, nikoliv pro drobné lokální vodoteče.

Zadruhé hydronyma nejsou přímo závislá na struktuře sídelní sítě a jejích proměnách. To znamená, že zatímco místní jména mohou zanikat během strukturálních změn osídlení, hydronyma přetrvávají.

Zatřetí tvorba hydronym, zvláště nižší hierarchie, není sociálně kontrolována do takové míry jako např. tvorba místních jmen. Podoba hydronym proto může odrážet jazyk sociálně minoritních skupin, zatímco podoba místních jmen ho může zastírat. To platí zvláště tehdy, pokud je jazyk nositelem významných sociosymbolických aspektů.

Z výše uvedeného je zřejmé, že prostorové rozšíření hydronym se slovanskými jazykovými prvky se může stát klíčovým ukazatelem toho, zda jazykově slovanské komunity přicházely do neosídlené oblasti, či jen prostupovaly volné enklávy mezi jazykově německými komunitami. Samozřejmě, že realita byla méně vyhraněná a závislá především na hierarchii jednotlivých hydronym. Ostrý obraz imigračního kontextu mohou rozmělnit hydronyma menšího významu, která se chovají jako pomístní jména nejnižší hierarchie, kterými jsou např. tratoová jména.

\subsection{Identifikační kritéria}

Předtím než přikročíme k analýze hydronym a místních jmen, je třeba alespoň předběžně modelovat různé varianty sociálního kontextu, které v severovýchodním Bavorsku mohly vést $\mathrm{k}$ jazykovému kontaktu. Jednotlivé ideální varianty definujeme jednoduchým způsobem a ze sociální perspektivy plošně, stranou ponecháme skutečnou variabilitu v rámci jednotlivých tříd/ranků, domén a sítí. Tuto variabilitu naopak zohledníme v tabulkově prezentovaných příkladech (tab. 6-8).

\section{Imigrace}

Mluvčí slovanského jazyka pronikají mezi mluvčí germánského nebo časně německého jazyka. Slovanská onymie vzniká na pozadí onymie germánsko-časně německé.

Výsledek jazykového kontaktu může být velmi rozrůzněný v závislosti na mnoha sociálních, demografických, sídelně-geografických a chronologických faktorech. Například na těsnosti kontaktu, délce kontaktu, velikosti populací a postoji mluvčích. V extrémním případě se v onymické soustavě nemusí vůbec žádné pozůstatky slovanského jazyka zachovat. Nicméně obvykle se přítomnost slovanského jazyka odrazí alespoň v jazykově smíšených jménech (definice v kap. 7.2). Dochování jednoduchých slovanských místních jmen je pak závislé na tom, do jaké míry se v imigračním kontextu vytvářely slovanské jazykové ostrovy.

Důležitým rozpoznávacím kritériem imigračního kontextu bude 1) př́itomnost a jazyková kontinuita starší germánské a časně německé onymie (tab. 6), 2) významný podíl jazykově smíšených jmen, 3) absence slovanských hydronym a pomístních jmen vyšší hierarchie. 


\begin{tabular}{|c|c|c|c|c|}
\hline němčina & \multicolumn{4}{|c|}{ slovanský jazyk } \\
\hline $\begin{array}{l}\text { všechny personálni } \\
\text { sité }\end{array}$ & & $\begin{array}{l}\text { personálni sit lokálnich } \\
\text { venkovských komunit }\end{array}$ & & $\begin{array}{l}\text { personálni sit' agentü } \\
\text { dálkové smény }\end{array}$ \\
\hline *Kambos ${ }^{x}$ & & - & & - \\
\hline \multicolumn{5}{|l|}{$\downarrow$} \\
\hline *Champ (dativ: /zi/ Chambe) & $\rightarrow$ & *Kǫba & $\leftrightarrow$ & *Kǫba \\
\hline \multirow{3}{*}{$\downarrow$} & & $\downarrow$ & & $\downarrow$ \\
\hline & & *Kúba & & *Kúba \\
\hline & & & & $\downarrow$ \\
\hline Chamb & & - & & Kouba \\
\hline jméno dodnes živé & & vymření jmén $a^{x x}$ & & jméno dodnes živé \\
\hline
\end{tabular}

${ }^{x}$ Keltský výchozí tvar.

${ }^{x x}$ Pokud by nešlo o hydronymum vysoké hierarchie, pak by nebylo užíváno v doméně dálkových vztahů a jeho slovanská podoba by zmizela beze stop.

Uvést konkrétní příklad vývoje slovansko-německého jmenného páru v imigračním kontextu je obtížné, nebot' slovanský člen obvykle beze stop zanikl. Zde uvedený prŕíklad je kompromisní. Slovanský člen jmenného páru známe díky tomu, že slovanský jazyk zcela nevymřel, ale v podobě češtiny se uchoval v doméně ,dálkové vztahy“.

Tab. 6. Hypotetický vývoj a realizace jména řeky Kouba (Cham) v Horní Falci. Př́íklad vývoje jmenného páru v imigračním kontextu slovansko-německého jazykového kontaktu, kdy je sociálně dominantní něměina. Podle Greule 2014, 82; Berger 1990/1991, 103.

Tab. 6. Hypothetische Entwicklung und Realisierung des Flussnamens Kouba (Chamb) in der Oberpfalz. Beispiel für die Entwicklung eines Namenpaars im Immigrationskontext des slawisch-deutschen Sprachkontakts bei sozial dominantem Deutsch. Nach Greule 2014, 82; Berger 1990/1991, 103.

\section{Imigrace - bilingvní sídelní postup}

Mluvčí slovanského i německého jazyka jsou začleněni do komunit, které se společně účastní sídelního postupu. Lze si představit velmi rozmanité scénáře, od slovanských komunit prostoupených několika bilingvními jedinci až po situace, ve kterých dominují němečtí mluvčí. Klíčové je sociální rozvržení a vztahy mluvčích. Slovanská onymie vzniká zčásti na pozadí onymie německé, zčásti nezávisle. Pokud nevzniknou jazykové ostrovy, pak se přítomnost slovanského jazyka většinou neprojeví, popř. pouze v jazykově smíšených jménech.

Rozpoznávací kritéria tohoto sociálního kontextu jsou podobná jako v předchozím př́ípadě, s výjimkou chronologického vztahu obou jazyků. Tedy 1) německá i slovanská onymická soustava se jeví jako stejně staré, a 2) počátek jazykového kontaktu je datován do stejného období jako počátky osídlení.

\begin{tabular}{|c|c|}
\hline $\begin{array}{c}\text { slovanský jazyk } \\
\text { personálni sit' lokálnich venkovských komunit }\end{array}$ & $\begin{array}{c}\text { němčina } \\
\text { všechny personálni sitě }\end{array}$ \\
\hline $\begin{array}{c}* \text { Chъlmbna } \\
\downarrow \\
* \text { Cholmna }\end{array}$ & $\begin{array}{c}\text { *Kulmenaha } \\
\downarrow \\
\text { *Kulmnach } \\
\downarrow \\
\text { Kulmbach }\end{array}$ \\
\hline vymření jména & jméno dodnes živé \\
\hline
\end{tabular}

* Jazykově smíšené jméno.

Tab. 7. Hypotetický vývoj jména potoka Kulmbach v Horních Francích. Podle Schwarz E. 1960, 312; Greule $2014,290$. „Conquest" kontext slovansko-německého jazykového kontaktu. Sociálně dominantní němčina.

Tab. 7. Hypothetische Entwicklung des Bachnamens Kulmbach in Oberfranken. Nach Schwarz E. 1960, 312; Greule 2014, 290. Kontext vom Typ „,conquest“ des slawisch-deutschen Sprachkontaktes. Sozial dominantes Deutsch.

\section{„Conquest“"}

Oblast osídlená primárně jazykově slovanským obyvatelstvem je integrována do mocenských a sociálních struktur, ve kterých dominuje německý jazyk, případně dojde i k masivní 
migraci německých mluvčích. Starší slovanská onymie je integrována do německé (tab. 7). Ideálním výsledkem tohoto „conquest“ kontextu je slovanská onymie dochovaná ve všech hlavních onymických kategoriích, samozřejmě v podobě integrované do němčiny. Mladší, primárně německá onymie je velmi fragmentární zejména v kategorii hydronym vyšší hierarchie.

V principu lze očekávat, že „conquest“ sociální kontext jazykového kontaktu vytvoří podmínky pro bilingvní sídelní postup zmíněný výše. Oblasti „conquest“ by v takových případech měly být lemovány oblastmi, které se jeví jako výsledek „immigration“ sociálního kontextu jazykového kontaktu.

\section{Opakovaný „conquest“}

Tato varianta „conquest“ popisuje situaci, kdy se slovanský jazyk šǐŕi do již dříve osídlených oblastí, které jsou jazykově německé, popř. ještě germánské. Na rozdíl od kontextu „immigration“ je však slovanský jazyk bud' sociálně dominantní, nebo jsou oba jazyky relativně sociálně symetrické (mocenské vakuum). K expanzi slovanského jazyka přitom může dojít různými způsoby. Tedy jak fyzickou migrací jazykově slovanských komunit, tak přechodem jazykově germánského obyvatelstva na slovanský jazyk (shrnuje Boček 2014). Teprve v další fázi je slovansky hovořící populace, at' je její geneze jakákoliv, integrována do struktur, v nichž byla sociálně dominantní němčina.

Výsledek jazykového kontaktu je podmíněn tím, do jaké míry během bilingvního období přešla původní populace jako celek na prestižnější slovanský jazyk. V každém případě platí, že jazykový kontakt probíhající v kontextu „opakovaný conquest“ indikují především slavizovaná předslovanská jména reintegrovaná později opět do němčiny (tab. 8).

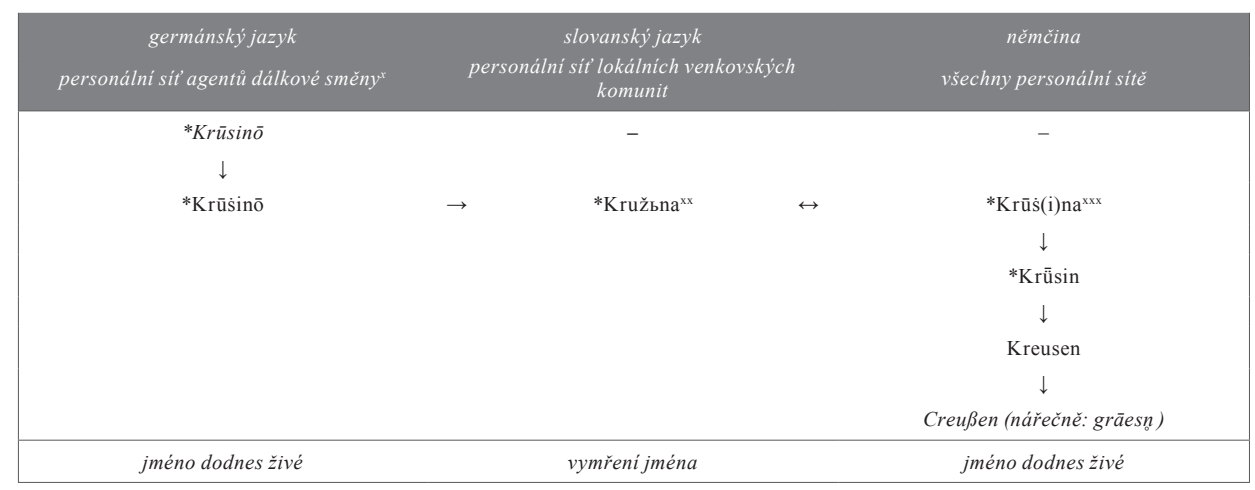

\footnotetext{
x Řeka protéká regionem bez dokladů kontinuitního osídlení.

xx Slavizace jména.

xxx Starofrancký tvar jména (starobavorský *Chrūsina).
}

Tab. 8. Hypotetický vývoj a realizace jména řeky Creußen v Horní Falci. „Conquest“ kontext slovansko-německého jazykového kontaktu. Sociálně dominantní zprvu slovanský jazyk, pak němčina. Podle Greule 2014, 83; Pokorny 2005; Eichler et al. 2006, 76-77.

Tab. 8. Hypothetische Entwicklung und Realisierung des Flussnamens Creußen in der Oberpfalz. Kontext vom Typ „conquest" des slawisch-deutschen Sprachkontaktes. Sozial zunächst dominante slawische Sprache, dann Deutsch. Nach Greule 2014, 83; Pokorny 2005; Eichler et al. 2006, 76-77.

\section{ANALÝZA / VÝPOVĚĎ TOPONYM}

\section{Hydronyma}

Klasifikace, chronologie a analýza hydronym byla detailněji prezentována $\mathrm{v}$ jiné studii, na kterou odkazujeme (Klír 2015, 181-193; aktualizovaně Klír v tisku). Tamtéž lze nalézt také prŕíslušné katalogy hydronym uspořádaných podle jednotlivých modelových vrstev. Zde se proto omezíme jen na nezbytné informace. 
Pro řešení námi formulovaného problému lze společně pojednat jména předgermánského a germánsko-časně německého původu, která vykazují jazykovou kontinuitu do němčiny bez slovanského jazykového zásahu (dále jen germánsko-časně německá jména; obr. 2-3). Pokud jde o dobu jejich vzniku, pak nejmladší z nich mohla vznikat ještě v 7.-8. století (některá jména s /-aha/; terminus ante quem 9. století).

Zatímco germánsko-německá hydronyma lze často chronologicky zařadit podle jejich slovotvorby, u slovanských to možné není (obr. 4). Pouze v některých př́ípadech lze určit období integrace slovanských hydronym do němčiny, a to na základě hláskových interferenčních jevů. Sídelně-historickou interpretaci hydronym komplikuje možnost transonymizace (Klír 2015, 187-193).

Pro interpretaci prostorového rozložení hydronym využijeme bodové znázornění, v němž je každé hydronymum položeno na místo, kde ústí vodní tok, který pojmenovává. Bodové znázornění, na rozdíl od liniového, má především komparační význam, nebot' umožňuje porovnat prostorové rozšíření hydronym s rozšířením různých typů místních jmen a s archeologickými lokalitami. Při interpretaci je třeba počítat s tím, že hranice oblasti, kde je rozšířena hydronymie určitého jazyka, je vždy posunuta od pramenů směrem k ústí. Pokud jde o vlastní analýzu prostorového rozložení hydronym, musíme vyloučit hydronyma s nejistou nebo méně přesvědčivou etymologií (Klír 2015, 193-205).

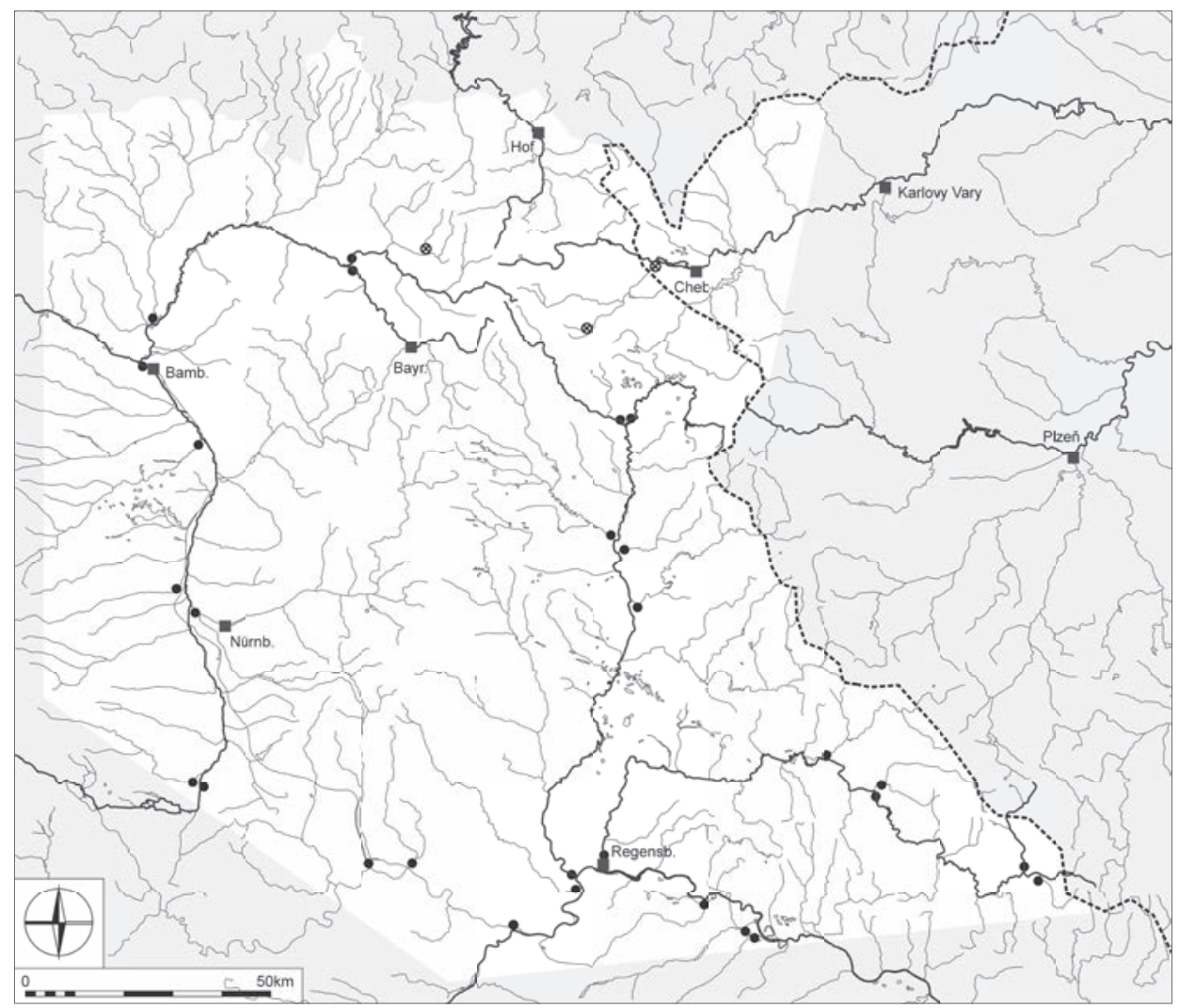

Obr. 2. Hydronyma předgermánského původu v severovýchodním Bavorsku a na Chebsku. Křížek v kruhu - sporná předgermánská hydronyma.

Abb. 2. Hydronyme vorgermanischen Ursprungs in Nordostbayern und im Egerland. Kreuz im Kreis - umstrittene vorgermanische Hydronyme. 


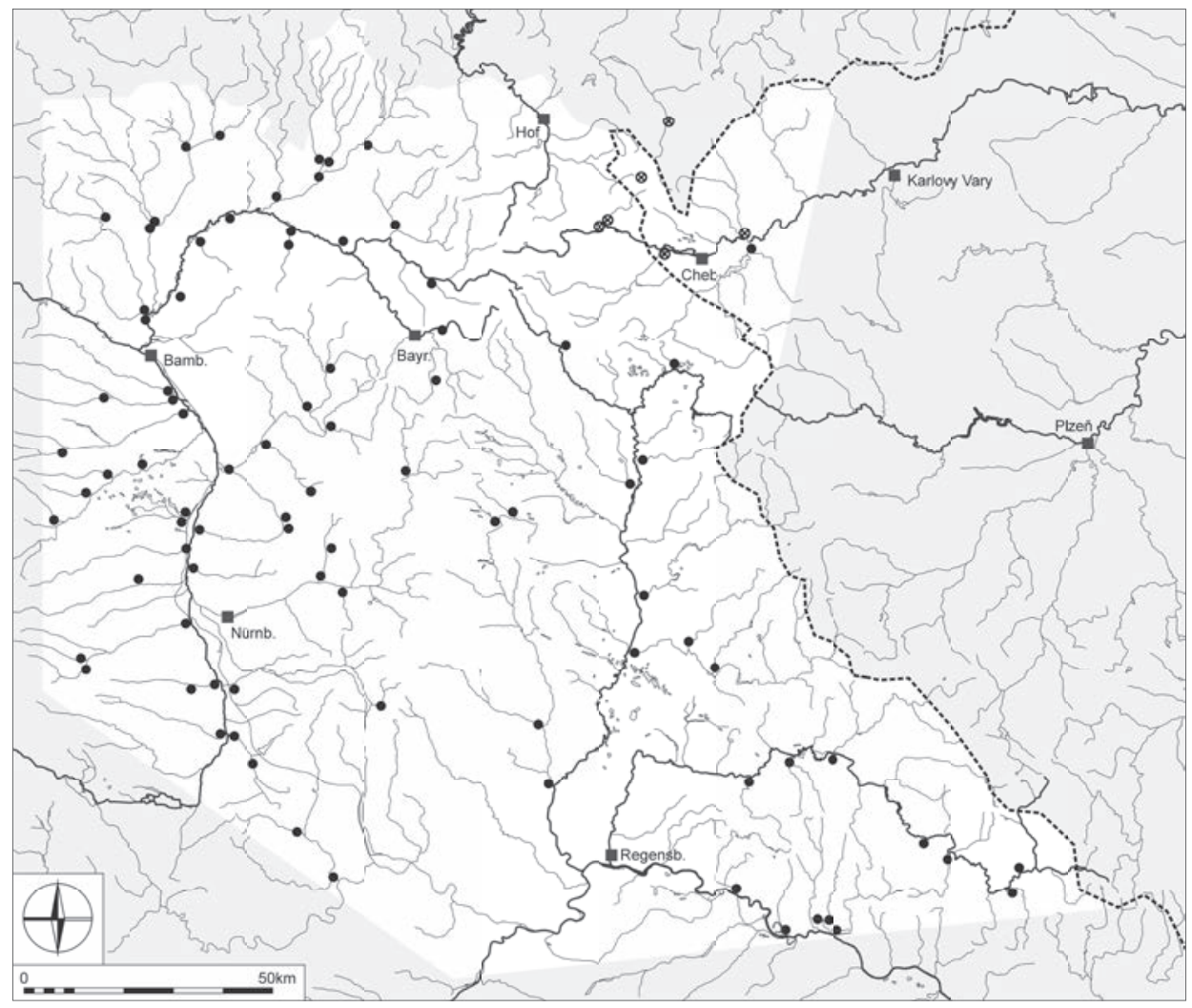

Obr. 3. Hydronyma germánského a časně-germánského původu v severovýchodním Bavorsku a na Chebsku. Kř́̌̌̌k v kruhu - sporná germánská a germánsko-časně německá hydronyma.

Abb. 3. Hydronyme germanischen und germanisch-frühdeutschen Ursprungs in Nordostbayern und im Egerland. Kreuz im Kreis - umstrittene germanische und germanisch-frühdeutsche Hydronyme.

\section{Předgermánská a germánsko-časně německá hydronyma}

Hydronyma předgermánského a germánsko-časně německého původu se v horním Pomohaní souvisle a hustě řetězí v celém povodí řek Regnitz/Rednitz a Itz. Souvisle jsou také zastoupena v povodí Rodachu, a jednotlivě až k soutoku Červeného a Bílého Mohanu. V Horní Falci je těchto hydronym méně a souvisle se řetězí pouze na Dunaji, Řezné a Schwarzachu. V horním Poohří (Chebsko) jsou germánsko-časně německá hydronyma zastoupena vzácně.

Posuzovaná hydronyma jsou důkazem germánsko-německé jazykové kontinuity, která začala nejpozději někdy v 8. století, ve velkém množství případů však jistě již mnohem dříve. Nicméně otázkou je, jaké personální sítě byly nositelkami této kontinuity a v jakých jazykových doménách byly germánské a časně německé tvary hydronym nejdřive a kontinuitně realizovány. Konkrétně, kde mohla být kontinuita zajištěna venkovským obyvatelstvem, a kde pouze sociálními elitami a agenty „dálkového kontaktu“. Tuto otázku lze řešit zčásti v konfrontaci se slovanskými hydronymy a zčásti s archeologickými nálezy.

Rozhodujícím kritériem, podle kterého lze určit, že nositelem jazykové kontinuity určitého hydronyma mohla/nemohla být venkovská populace, at' byl její jazyk jakýkoliv, je přirozeně prrítomnost/nepřítomnost archeologických dokladů př́íslušného kontinuitního osídlení v regionu. Pokud se hydronymum nachází v oblasti bez spolehlivých archeologických dokladů trvalého venkovského osídlení, mohlo být kontinuitně realizováno pouze v jazykové doméně „mocenské“ a „dálkové vztahy“ (tab. 9). 


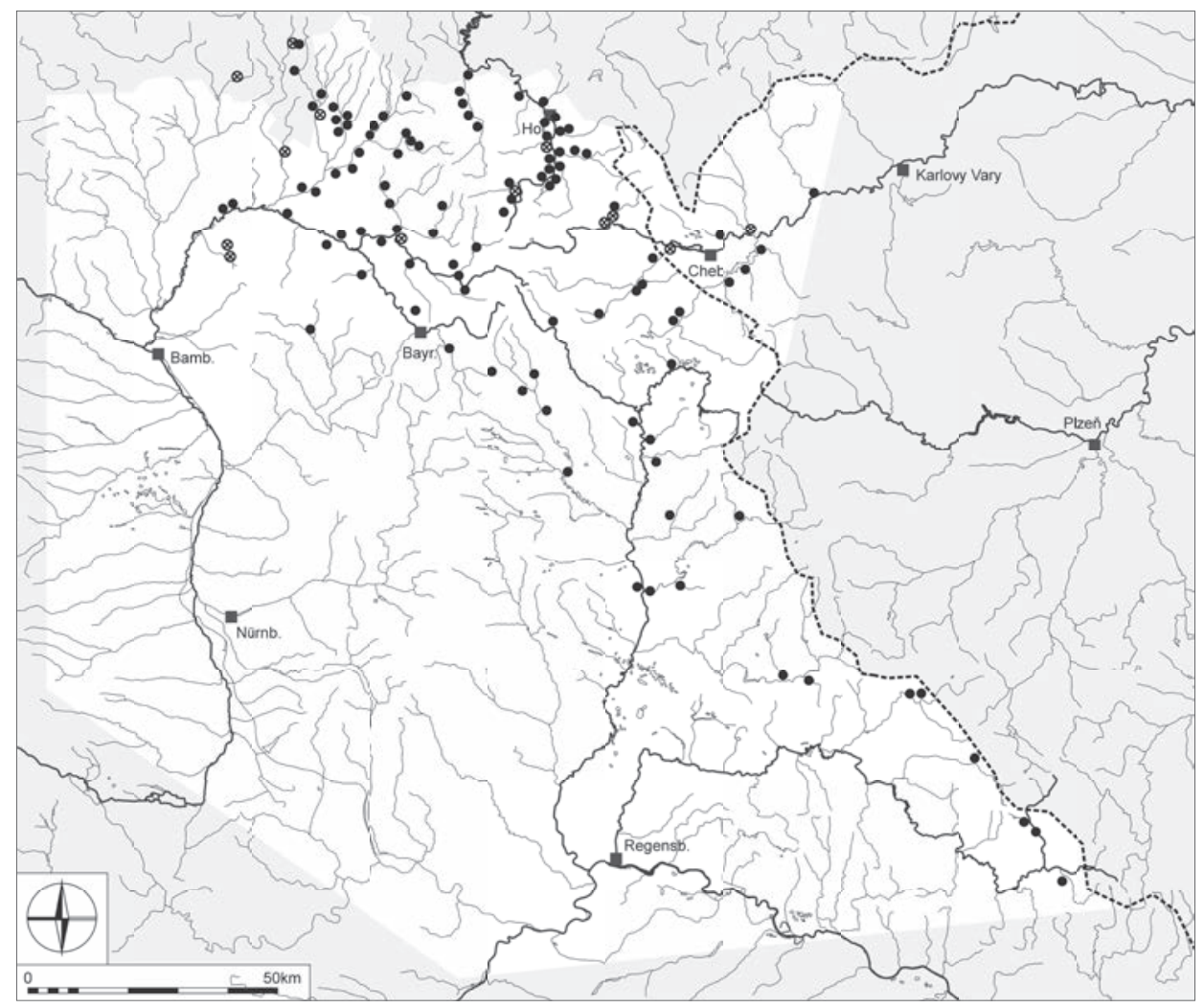

Obr. 4. Hydronyma slovanského původu v severovýchodním Bavorsku a na Chebsku. Křížek v kruhu - sporná slovanská hydronyma.

Abb. 4. Hydronyme slawischen Ursprungs in Nordostbayern und im Egerland. Kreuz im Kreis - umstrittene slawische Hydronyme.

\begin{tabular}{|c|c|c|c|}
\hline \multicolumn{2}{|c|}{ A } & \multicolumn{2}{c|}{ B } \\
\hline Hydronymum & Výchozi tvar & Hydronymum & Výchozí tvar \\
\hline Wondreb & *Wundraha & Röslau & *Rosila (> *Rosilaha) \\
\hline Schweinenaab & *Swinaha & Selb & *Salwina \\
\hline Wiesau & *Wisaha & Fleißen & *Flīsana \\
\hline Floß & *Flūtō & "Trewina & *Drawina \\
\hline Höllbach & *Swurbaha & & \\
\hline
\end{tabular}

Tab. 9. Sufixální hydronyma předgermánského a germánsko-časně německého původu, jejichž kontinuitní vývoj do němčiny mohl proběhnout pouze v jazykové doméně „dálkové vztahy“. A - etymologie nesporné; B - etymologie z různých důvodů do jisté míry kontroverzní (srov. Klír 2015, 194-206; Greule 2014; Pleintinger 2008).

Tab. 9. Suffixale Hydronyme vorgermanischen und germanisch-frühdeutschen Ursprungs, deren Entwicklungskontinuität ins Deutsche nur in der Sprachdomäne „Fernbeziehungen“ verlaufen konnte. A - Etymologie unstrittig; B - Etymologie aus verschiedenen Gründen bis zu einem gewissen Grad kontrovers (vgl. Klír 2015, 194-206; Greule 2014; Pleintinger 2008).

\section{Slovanská hydronyma}

Společně lze pojednat hydronyma slovanského původu a předslovanská, ale v průběhu času slavizovaná jména (nadále jen slovanská hydronyma). Pokud jde o chronologii, pak slovanská jména mohla vznikat od ca 8 . až do 12 . století. Období jejich produktivity se proto zpočátku protnulo ještě s produktivitou časně německých hydronym s /-aha/, což dokládají i některá jazykově smíšená hydronyma (tab. 11). 
Rozložení hydronym slovanského původu v severovýchodním Bavorsku ukazuje nápadné kontrasty. Souvisle se řetězí na horním Rodachu a v horním Posálí (Francký les a Smrčiny). V Posálí slovanská hydronyma dokonce pojmenovávají kostru vodní sítě. Rozptýleně pak slovanská hydronyma leží mezi severními přítoky horního Mohanu. Nejzápadněji vysunutá slovanská hydronyma jsou zároveň ta, která se jako první objevují v písemných pramenech (Schney, Kösten; 9. století [kopie z 12. století]; srov. George 2008, 33-34). Naopak slovanská hydronyma, až na jednu výjimku, chybí v povodí Regnitz/Rednitz. V Horní Falci jsou jména slovanského původu rozptýlena pouze v její severní a východní části. Nápadná je skupina pravděpodobně poměrně pozdně vzniklých hydronym na Šumavě, při hranicích s Čechami. Jména slovanského původu jsou jednotlivě zastoupena také v horním Poohří (Chebsko), kde navazují na slovanskou hydronymii západních Čech.

\section{Srovnání prostorové distribuce}

Hydronyma germánsko-časně německého a slovanského původu se z velké části vylučují, a to tak, že tam, kde končí oblast souvislého rozšíření germánsko-časně německých hydronym, tam začínají slovanská hydronyma (obr. 5). V některých regionech se ale oba typy hydronym naopak prolínají. Rozlišit tak lze čtyři hlavní situace:

1) Oblasti, kde jsou souvisle zastoupena germánsko-časně německá hydronyma a zároven̆ chybi slovanská hydronyma. Pokud archeologie dokládá časově příslušné osídlení, pak germánsko-časně německá hydronyma zde mohla být realizována ve všech jazykových doménách a sociálních třídách (tab. 12:1). To ovšem nutně neznamená, že také ve všech lokálních personálních sítích, z nichž některé mohly být jazykově slovanské. $V$ tom př́ípadě by zde slovanská hydronyma vznikala na základě primárních germánsko-německých hydronym, a proto později zanikla beze stop. Indikátorem území, kde mohl být vedle německého realizován i slovanský jazyk, je přítomnost slovanských místních jmen (blíže kap. 7.3).

2) Oblasti, kde se prolinají germánsko-némecká a slovanská hydronyma (tab. 12:2). Tato onymická situace může být interpretována dvěma způsoby. Zaprvé jde o výsledek chronologicky nebo geograficky rozdílného sídelního postupu neseného jazykově rozdílnými komunitami, což mělo za následek jazykově mozaikovitý charakter hydronymie. Nebo zadruhé jde o výsledek sociálně rozdílné realizace germánsko-německého a slovanského jazyka (tj. o výsledek diglosie). Kritériem, které umožňuje tyto dvě interpretační možnosti rozlišit, je srovnání hierarchie germánsko-časně německých a slovanských hydronym (tab. 10).

\begin{tabular}{|c|cc|}
\hline Délka & Germánsko-německá & Slovanská \\
\hline do $\mathbf{1 0} \mathbf{~ k m}$ & 4 & 33 \\
$\mathbf{1 1 - 2 0 ~} \mathbf{~ k m}$ & 3 & 3 \\
$\mathbf{2 1 - 3 0 ~ k m ~}$ & 2 & 0 \\
nad $\mathbf{3 1 ~ k m}$ & 7 & 0 \\
neurčitelné & 7 & 5 \\
\hline Počet & 16 & 41 \\
\hline
\end{tabular}

Tab. 10. Délka vodních toků s germánsko-německým a slovanským pojmenováním v oblasti společného výskytu v horním Pomohaní.

Tab. 10. Länge der Wasserläufe mit germanisch-deutscher und slawischer Benennung im gemeinsamen Vorkommensbereich im Obermaingebiet.

Tabulka ukazuje velmi nápadný rozdíl mezi vodními toky s germánsko-časně německými a slovanskými jmény. Germánsko-časně německá jména se váží na významné vodní toky, tj. na kostru vodní sítě, a naopak slovanská pojmenování jsou vázána většinou na lokální vodní toky, často nejnižšího řádu. Taková kontrastní distribuce svědčí pro druhou variantu, tedy pro sociálně rozdílnou realizaci obou jazyků. Konkrétně germánsko-časně německá hydronyma byla zprvu realizována jen v doméně „mocenské struktury“ a „dálkové vztahy“. Naopak nositelem slovanských hydronym bylo venkovské obyvatelstvo. 
Druhá indicie toho, že primárním jazykem venkovských komunit v regionu byl slovanský jazyk, jsou jazykově smíšená hydronyma (tab. 11). Některá z nich navíc dokládají integraci slovanských hydronym ještě v období produktivity hydronym s /-aha/ (Schwarz E. 1960, 229-230, 312; tab. 12:2).

\begin{tabular}{|cccccccc|}
\hline$*$ Chъlmьna & $\rightarrow$ & $*$ Cholmna & $\rightarrow$ & Culminaha & $\rightarrow$ & Kulmbach \\
\hline *Dăbra & $\rightarrow$ & $*$ Dobra & $\rightarrow$ & $*$ Dobraha & $\rightarrow$ & Dobrachbach \\
\hline${ }^{*}$ Ch(v)ojına & $\rightarrow$ & Kainach & & & & \\
\hline
\end{tabular}

x alternativní výklad: starohornoněmecké *Kīnaha

Tab. 11. Vývoj jazykově smíšených jmen s /-aha/. Podle Eichler et al. 2006, 115-117; Greule 2014, passim; Schwarz E. 1960, passim; Sperber 1970, passim.

Tab. 11. Entwicklung der sprachlich gemischten Namen mit/-aha/. Nach Eichler et al. 2006, 115-117; Greule 2014, passim; Schwarz E. 1960, passim; Sperber 1970, passim.

3) Oblasti, kde jsou evidována slovanská hydronyma a zároveň chybí germánsko-časně německá hydronyma. Interpretace těchto oblastí závisí na dataci a rozsahu nejstaršího osídlení. Pokud je zde osídlení doloženo již před 8.-9. stoletím, pak zde jak venkovská populace, tak i sociální elity mohly být původně jazykově pouze slovanské (tab. 12:3a; tato situace však není nikde doložena). V př́ípadě, že existuje doklad nejstaršího osídlení až od 9. století a později, není jednoznačná interpretace sociální distribuce slovanského jazyka možná, nebot' jazykově německé venkovské komunity zde mohou být skryty za kompozitními hydronymy s /-bach/ (tab. 12:3 b). Pro řešení přichází v úvahu stejné možnosti jako v případě 2), tedy důležité je posoudit hierarchii vodních toků se slovanskými a německými hydronymy, včetně jejich četnosti. Pohled na obr. 4-5 přitom ukazuje, že jedinou rozsáhlejší oblastí, kde se slovanská hydronyma váží na významnější vodní toky než německá hydronyma, je horní Posálí, osídlované však relativně pozdě v 11.-12. století.

4) Oblasti, kde chybi jak germánsko-časně německá, tak slovanská hydronyma (tab. 12:4). Tyto oblasti by měly být osídlovány až $\mathrm{v}$ období, kdy v němčině dominovala složená hydronyma s /-bach/. Slovanští mluvčí se na sídelním postupu bud' nepodíleli, nebo jen v imigračním kontextu v rámci bilingvního sídelního postupu. Dokladem přítomnosti slovanských mluvčích mohou být slovanská místní jména (srov. kap. 7.3).

Situace uvedené pod body 1 a 4 indikují oblasti, kde byla vodní sít’ pojmenovávána nejdříve v německém jazyce a slovanská názvotvorba se uplatňovala druhotně. K jazykovému kontaktu zde tak došlo v imigračním kontextu. Oblast charakterizovaná v bodu 2 naznačuje původně spíše průchozí oblast, ve které byla velmi časně pojmenována kostra vodní sítě (germánsky/německy), a pro primárně slovanskou názvotvorbu tak zůstaly volné jen méně důležité vodní toky. K jazykovému kontaktu zde došlo později v rámci „conquest“ kontextu, stejně jako v oblasti uvedené pod bodem 3 .

\begin{tabular}{|c|c|}
\hline Oblast & Regiony \\
\hline 1. & $\begin{array}{l}\text { Většina sledované oblasti. Celé Pomohaní mimo východní okrajové části. Západní, jižní a střední } \\
\text { Horní Falc. }\end{array}$ \\
\hline 2. & Východní horní Pomohaní. V Horní Falci pouze malé území na střední Nábě. \\
\hline 3a. & $\begin{array}{l}\text { Tato situace v severovýchodním Bavorsku není evidována, lze se s ní ale setkat v sousedních } \\
\text { Čechách a v Sasku. }\end{array}$ \\
\hline 3b. & Horní Posálí. \\
\hline 4. & $\begin{array}{l}\text { Hornofalcký les, Halštrovské vrchy a velká část Smrčin. Oblasti sídelního postupu 11.-12. století, } \\
\text { což potvrzují i další kategorie a typy vlastních jmen (německá mýtební jména), popř. také již } \\
\text { písemné prameny (Schwarz E. 1960a, Deckblatt 8). }\end{array}$ \\
\hline
\end{tabular}

Tab. 12. Geografická specifikace základních typů oblastí podle distribuce germánsko-časně německých a slovanských hydronym.

Tab. 12. Geographische Spezifikation der Gebietsgrundtypen gemäß der Distribution von germanisch-frühdeutschen und slawischen Hydronymen. 


\section{Výpověd' místních jmen}

Analýza prostorového rozšíření germánsko-časně německých a slovanských hydronym poskytla základní představu o rozmanitých sociálních souvislostech jazykového kontaktu v různých částech severovýchodního Bavorska a Chebska. Kontrolu a detailnější pohled nabízí rozložení místních jmen.

\subsection{Místní jména jazykově germánského a německého původu}

Chronologická výpověd' jednotlivých typů německých místních jmen byla v minulosti přeceňována a někdy vedla $\mathrm{k}$ falešné představě o sídelně-historickém vývoji. Platí sice, že určité typy germánských a německých jmen byly preferovány v určitém období, ale zároveň také, že všechny typy mohly jednotlivě vznikat kdykoliv, a to i dlouho po období své vrcholné produktivity. Takový pozdní vznik mohl být způsoben 1) analogickým tvořením, 2) sekundárním vývojem, tj. adaptací z jiného typu, a 3) transferem jména. Z toho důvodu nelze jednotlivá místní jména interpretovat samostatně, ale vždy v rámci celé onymické soustavy, a samozřejmě v konfrontaci s aktuálním archeologickým a historickým poznáním. Pokud jde o chronologické určení vrcholné produktivity německých typů germánských a německých místních jmen, můžeme navázat jak na obecné poznatky (napr. Debus 2012, 138-191; Debus-Schmitz 2004; Bach 1953; 1954), tak na studie věnující se př́mo severovýchodnímu Bavorsku (Schwarz E. 1960; Andraschke 2007; monografie v rámci projektu „Historisches Ortsnamenbuch von Bayern“, nověji: Fastnacht 2000; 2007; George 2008).

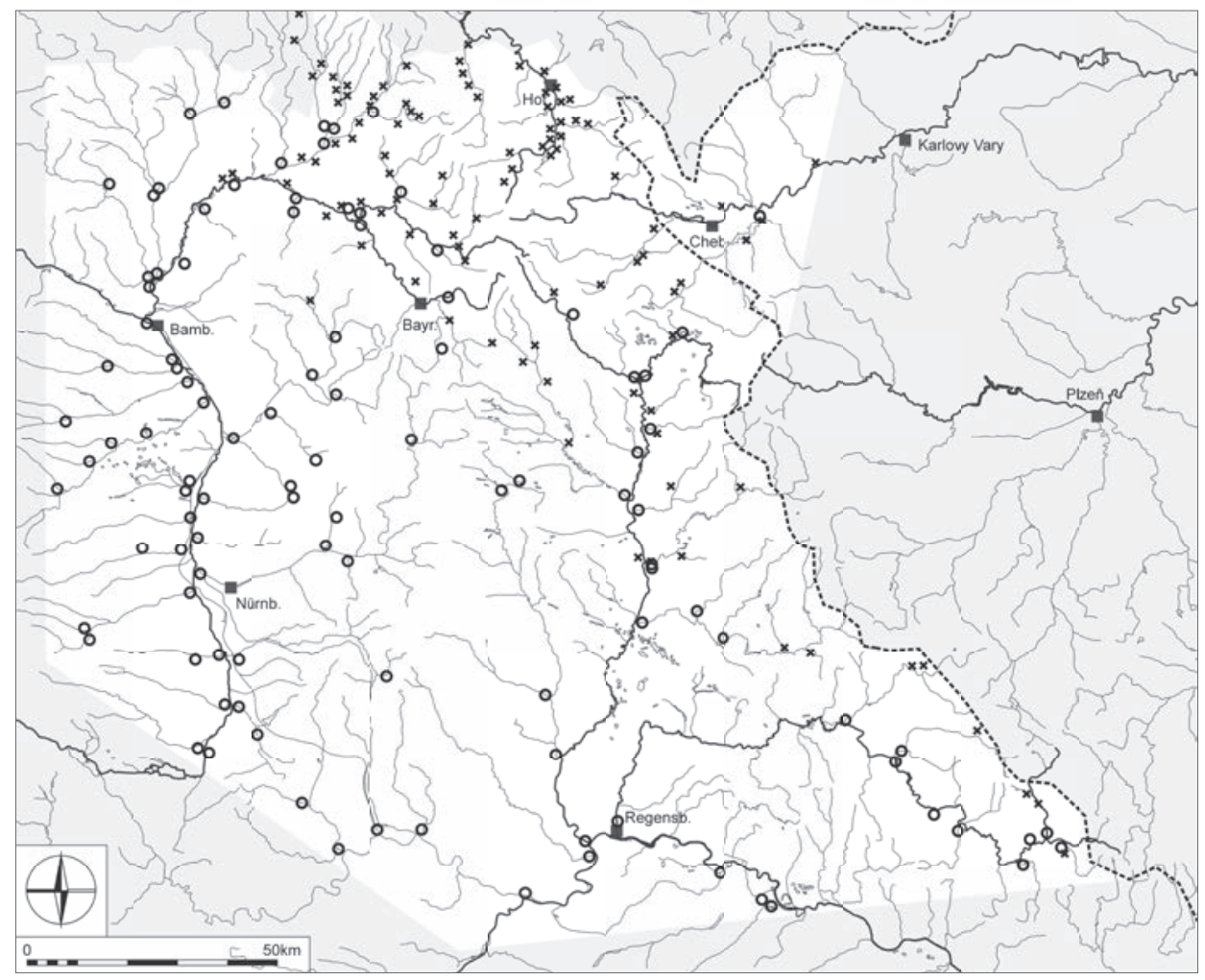

Obr. 5. Předgermánská a germánsko-časně německá hydronyma (kolečko) a slovanská a slavizovaná předslovanská hydronyma (křížek) - srovnání prostorové distribuce v severovýchodním Bavorsku a na Chebsku.

Abb. 5. Vorgermanische und germanisch-frühdeutsche Hydronyme (Punkt) und slawische und slawisierte vorslawische Hydronyme (Kreuz) - Vergleich der räumlichen Distribution in Nordostbayern und im Egerland. 
Ve sledované oblasti jsou důležité typy jmen, které byly charakteristické již pro germánské období (tzv. předfrancké typy jmen, před ca 700/750). Jde o některá „archaická“ sufixální jména, dále o sufixální jména s patronymickou př́íponou /-ing/ a o kompozita se základním slovem /-heim/, /-statt/ a /-mar/. Důležité je, že v horním Pomohaní do těchto typů jmen - až na výjimky - nevstoupila slovanská osobní jména. To znamená, že vrchol produktivity těchto typů ležel ještě v jazykově předkontaktním období. Zároveň to opět potvrzuje, že slovansko-germánsko/německý jazykový kontakt začal relativně pozdě, a to až v 8.-9. století (Andraschke 2007, 301-308). Jedinou oblastí, kde se hojně vyskytují jména s patronymickou př́íponou /-ing/a slovanským osobním jménem, popř. apelativem, je komunikačně mimořádně důležité údolí Kouby („Cham-Further Senke“) na jihovýchodě Horní Falce, představující klíčovou spojnici Čech a Podunají (Schwarz E. 1953; 1960, 57-60, 333). Nicméně právě deapelativní jazykově smíšená jména indikují sekundární a relativně pozdní způsob vzniku celé této skupiny jmen, a to v období, kdy př́ípona /-ing/ již nebyla produktivní (Schwarz E. 1960, 333; Janka 2003).

Další výraznou skupinu typů jmen tvoří ty, které sice již nepatří k tzv. všegermánskému toponymickému dědictví, ale v písemných pramenech jsou hojně doloženy od 8 . století. Opět platí, že řada tehdy běžných tvarů zůstala vzhledem ke své sémantické průhlednosti produktivní i v dalších obdobích (/-bach/, /-feld/, /-dorf/). Jiné ze jmenných typů se v 8.-9. století vázaly na určitý sociálně-ekonomický kontext, např. na systém královských dvorů (/-hofen/), nebo na šlechtické majetky (/-hausen/), a jejich výpověd' proto není reprezentativní.

Přes řadu omezení může být distribuce různých typů německých místních jmen indikátorem kontextu slovansko-německého jazykového kontaktu. Tam, kde se v onymické soustavě výrazně uplatňují typy jmen z tzv. všegermánského dědictví, můžeme oprávněně předpokládat primární jazykově germánsko-německé komunity, a tedy imigrační kontext slovansko-německého jazykového kontaktu.

\subsection{Slovanská místní jména}

Místní jména hypoteticky slovanského původu v celém severovýchodním Bavorsku eviduje rozsáhlá monografie E. Schwarze (1960), která však skrývá interpretační úskalí na mnoha rovinách (srov. Eichler 1962; 1963; 1999a; Wiesinger 1975). Systematický a kritický katalog slovanských místních jmen na základě Schwarzovy studie sestavil E. Eichler (1962). Další syntetickou studii představuje monografie erlangenského slavisty J. Schütze (1994), který demonstrativně popřel základní metody kontaktové onomastiky a svými intuitivními postupy se dostal do rozporu s celou západoslovanskou onomastikou (Klír 2015, 181). K revizi Schwarzových, a především Schützových výsledků došlo v rámci regionálně zaměřeného projektu „Bavaria Slavica“ (1996-2004), jehož hlavní výsledky již byly publikovány (Eichler et al. 2001; 2006; Eichler 2007).

Starší systematické přehledy slovanských místních jmen pro celé severovýchodní Bavorsko a Chebsko evidovaly přes 600 místních jmen jazykově slovanského původu (tab. 13; Schwarz E. 1960, Deckblatt 13; Eichler 1962; Fischer 1940). Samožrejmě toto číslo je pouze orientační. Dnes již takovouto vyhraněnou statistiku nelze sestavit, nebot' velká část onomastických rekonstrukcí je variantní, popř. konstruována s různou mírou pravděpodobnosti (tab. 14; srov. zvláště Eichler et al. 2001; 2006).

Místní jména se slovanskou etymologií jsou rozdělována do dvou hlavních skupin. Každá z nich přitom nese rozdílnou historickou výpověd'.

Do první skupiny patří tzv. jednoduchá slovanská místní jména (tab. 15:1). Tímto ne zcela přesným termínem zde označujeme německá místní jména vzniklá jednoduchou integrací původního slovanského toponyma do němčiny. Vnitřní typologické roztřídění těchto jmen - obvykle na základě strukturálně-typologických a lexikálně-sémantických kritérií - je komplikováno tím, že ne vždy je s jistotou rekonstruován výchozí slovanský tvar (Bily 2000, 27-29; Eichler et al. 2001; 2007, 238-239). Z toho důvodu v této studii nezacházíme do detailů, nýbrž všechna jednoduchá slovanská jména pojednáváme jako jednu skupinu. 


\begin{tabular}{|c|ccc|}
\hline Vládní kraj & Jednoduchá slovanská jména & Jazykově smíšená jména & Celkem \\
\hline Horní Falc a Dolní Bavorsko & 106 & 66 & 218 \\
Horní Franky & 269 & 105 & 374 \\
Střední Franky & 0 & 17 & 17 \\
Dolní Franky & 0 & 2 & 2 \\
Chebsko (česká část) & 33 & 11 & 44 \\
\hline Celkem & 408 & 201 & $\mathbf{6 0 9}$ \\
\hline
\end{tabular}

Tab. 13. Orientační přehled jednoduchých slovanských a jazykově smíšených místních jmen v severovýchodním Bavorsku. Rozdíl mezi počtem 655 (text) a 609 (tabulka) je dán v prvé řadě vyloučením transonymizovaných místních jmen. Podle Schwarz E. 1960; Eichler 1962; Fischer 1940.

Tab. 13. Orientierungsübersicht einfacher slawischer und sprachlich gemischter Ortsnamen in Nordostbayern. Der Unterschied zwischen der Anzahl 655 (Text) und 609 (Tabelle) ist in erster Linie durch den Ausschluss von transonymisierten Ortsnamen gegeben. Nach Schwarz E. 1960; Eichler 1962; Fischer 1940.

\begin{tabular}{|c|ccc|}
\hline Vládní kraj & Jednoduchá slovanská jména & Jazykově smišená jména & Celkem \\
\hline Horní Falc a Dolní Bavorsko & 97 & 79 & 176 \\
Horní Franky & 220 & 100 & 320 \\
Střední Franky & 0 & 17 & 17 \\
Dolní Franky & 0 & 0 & 0 \\
Chebsko (česká část) & 33 & 11 & 44 \\
\hline Celkem & 350 & 207 & $\mathbf{5 5 7}$ \\
\hline
\end{tabular}

Tab. 14. Orientační přehled jednoduchých slovanských a jazykově smíšených místních jmen v severovýchodním Bavorsku. Podle Eichler et al. 2006; 2001 (okresy Bamberg, Bayreuth); př́íslušných svazků Historisches Ortsnamenbuch Bayern a Historischer Atlas von Bayern; doplňkově Eichler 1962.

Tab. 14. Orientierungsübersicht einfacher slawischer und sprachlich gemischter Ortsnamen in Nordostbayern. Nach Eichler et al. 2006; 2001 (Bezirke Bamberg, Bayreuth); einschlägige Bände des Historischen Ortsnamenbuchs Bayern und des Historischen Atlas von Bayern; Ergänzend Eichler 1962.

Druhou skupinu představují složená, tzv. jazykově smíšená (hybridní) jména (Janka 2003; Eichler et al. 2001, 228-230; Eichler 1999; 2000; Bily 2000, 27; 2000a). Tato jména mohla vzniknout více způsoby - bud' integrací slovanského toponyma do němčiny (tab. 15:2a), nebo na základě uplatnění slovanského osobního jména v rámci německé názvotvorby (tab. 15:2 b). V prvém případě svědčí jazykově smíšené jméno o jinak nedochovaném slovanském toponymu. Ve druhém př́ípadě pouze o slovanské antroponymii. Bohužel až na několik výjimečných př́ípadů nelze genezi tzv. jazykově smíšených jmen rozpoznat, a platí tedy, že tato místní jména dokládají prŕmo slovanskou antroponymii, nikoliv toponymii.

Soustavu slovanských místních jmen charakterizuje derivační názvotvorba a velké množství př́íponových odvozenin. Slovanská onomastika proto vypracovala různé postupy umožňující relativní časové rozvrstvení hlavních typů místních jmen (např. Šmilauer 1960; Zschieschang 2003, 65-68, Abb. V/1). Jejich uplatnění v severovýchodním Bavorsku však není efektivní, především vzhledem $\mathrm{k}$ nejistotě $\mathrm{v}$ detailních rekonstrukcích (srov. Walther 1963). Z toho důvodu na tento způsob časového rozvrstvení rezignujeme.

Pevnější chronologické opory poskytuje jiný datační postup, tzv. substituční metoda, která vychází ze způsobu, jakým bylo hypotetické slovanské jméno integrováno do německého jazyka. Datace je v tomto př́ípadě těsně provázána s rekonstrukcí výchozího slovanského tvaru (Klír 2015, 179-180). Nicméně signifikantní chronologická informace je k dispozici jen pro některá místní jména, a tak nejcennější poznatek spočívá v základní informaci o periodě jazykového kontaktu (kap. 2.2) 


\begin{tabular}{|c|c|c|c|c|}
\hline & & Slovanský tvar & & Německý tvar \\
\hline 1. & místní jméno & *Dolınica & $>$ & Döllnitz \\
\hline 1. & místní jméno & *Goŕane & $>$ & Görau \\
\hline $\begin{array}{l}2 a . \\
2 b .\end{array}$ & $\begin{array}{l}\text { místní jméno } \\
\text { osobní jméno }\end{array}$ & $\begin{array}{l}\text { *Godomyšl-jь } \\
\text { *Godomyslı }\end{array}$ & $\begin{array}{c}+/ \text { dorf } /> \\
>\end{array}$ & ${ }^{*}$ Godmuzelsdorf ( $>$ Gottmannsdorf) \\
\hline $\begin{array}{l}2 a . \\
2 b .\end{array}$ & $\begin{array}{l}\text { místní jméno } \\
\text { osobní jméno }\end{array}$ & $\begin{array}{l}\text { *Dobroš-in } \\
\text { *Dobrošs }\end{array}$ & $\begin{array}{c}> \\
+/ \text {-ing } />\end{array}$ & *Tobirsingen (> Döbersing) \\
\hline
\end{tabular}

Tab. 15. Příklady jednoduchých slovanských a jazykově smíšených jmen. Podle Janka 2003, 35-36.

Tab. 15. Beispiele für einfache slawische und sprachlich gemischte Namen. Nach Janka 2003, 35-36.

\subsection{Srovnání prostorové distribuce}

Vzhledem k tomu, že slovanský jazyk byl v jazykově kontaktním období v Bavorsku a na Chebsku sociálně minoritní, znamená přitomnost slovanských místních jmen automaticky přítomnost jazykově slovanských venkovských komunit. Ovšem opačně to neplatí, přítomnost německých místních jmen jazykově německé venkovské komunity nedokládá a slovanské nevylučuje. Jinak řečeno, pokud byla němčina sociálně dominantním jazykem, slovanská jména všech kategorií budou podreprezentována, nebot' nemusela ovlivnit všechny jazykové domény, a naopak německá jména budou nadreprezentována, nebot' se mohla z jedné jazykové domény později rozšířit do domén všech.

\section{Archaické typy německých jmen}

Z analýzy je třeba zatím vyloučit skupinu zdánlivě archaických jmen ležících ve Smrčinách, nebot' jednak leží v oblasti s výrazně pozdně začínající sídelní kontinuitou a jednak se strukturálně liší od onymie starých sídelních oblastí v pomohanských Francích a historickém Bavorsku (Klír 2015, 204-205; opačně např. Schwarz E. 1960; Gütter 1989; Pleintinger 2008).

Zastoupení tzv. archaických typů německých jmen se v Pomohaní a Horní Falci navzájem velmi liší (typy /-ing/, /-heim/, /-statt/, /-mar/). V horním Pomohaní se archaická místní jména hojněji nikde neobjevují a jejich výskyt se omezuje jen na údolí Mohanu, Regnitz/Rednitz a některých jejich přítoků. Na pravobřeží horního Mohanu chybí, na levobřeží dosahují pouze úrovně říčky Weismain (obr. 6). Mírně větší rozptyl ukazují místní jména se základním slovem /-hofen-/ a /-hausen-/, která se koncentrují v okolí panovníkových falcí a panovníkových, popř. šlechtických centrálních dvorů (Andraschke 2007, 221, 225-227; Machilek 2007, 284-285, 290-291; Frank-Oelwein-Schuh 2002; Hensch 2011, 485-486). Naopak archaické typy místních jmen jsou zastoupeny ve velkém množství v jižní a střední Horní Falci. Důležitý je hustý výskyt v povodí Řezné, kde tzv. archaické typy německých jmen stoupají až do podhůř́i Šumavy a do komunikačně významné Koubské pánve.

Seskupení archaických typů německých místních jmen se bez výjimky vylučují se slovanskými hydronymy (obr. 7). Pokud se archaické německé jméno v oblasti slovanských hydronym nalézá, pak pouze izolovaně, a můžeme proto uvažovat o jeho relativně mladším vzniku. Negativní korelace seskupení archaických typů německých místních jmen a slovanských hydronym tak potvrzuje premisu, že obě tyto kategorie jsou poměrně spolehlivým ukazatelem sociálního kontextu jazykového kontaktu.

V oblastech s archaickými německými místními jmény jsou hojně zastoupena germánsko-časně německá hydronyma. Tam, kde germánsko-časně německá hydronyma vybíhají mimo oblast rozšíření archaických typů německých místních jmen, je třeba uvažovat o jejich uživání a předávání v rámci vyšších sociálních domén a personálních sítí (obr. 8). 


\section{Slovanská jména}

Slovanská místní jména všude překračují úroveň rozšíření slovanských hydronym, s výjimkou oblasti v okolí Alt-Banz v údolí Mohanu. Předpokládáme, že všude tam, kde chybí slovanská hydronyma, by slovanská místní jména měla indikovat imigrační kontext jazykového kontaktu a slovanské jazykové ostrovy. $Z$ toho důvodu je důležité sledovat 1) územní rozsah slovanských místních jmen, 2) podíl jazykově smíšených a jednoduchých místních jmen, 3) podíl slovanských místních jmen v onymii jako celku.

Slovanská místní jména se v severovýchodním Bavorsku vyskytují s nerovnoměrnou hustotou a vykazují určité seskupení (tab. 16; obr. 9-10). Odlišný je rovněž poměr jednoduchých slovanských a jazykově smíšených jmen. Můžeme pozorovat, že významnou hranicí je zóna, na které končí slovanská hydronyma (obr. 11). Na území se slovanskými hydronymy výrazně převažují jednoduchá slovanská jména nad jazykově smíšenými (celkem 388; z nich 22 \% jazykově smíšených). $\mathrm{Na}$ území bez slovanských hydronym je situace přibližně vyrovnaná (celkem 237 ; z nich $45 \%$ jazykově smíšených). Obecně přitom platí, že hustota slovanských místních jmen klesá, a v jejich rámci podíl jazykově smíšených místních jmen naopak stoupá - v horním Pomohaní z východu na západ a v Horní Falci ze severu na jih. Markantní je tento jev ve středních Francích, kde jednoduchá slovanská místní jména chybí a zastoupena jsou pouze místní jména jazykově smíšená.

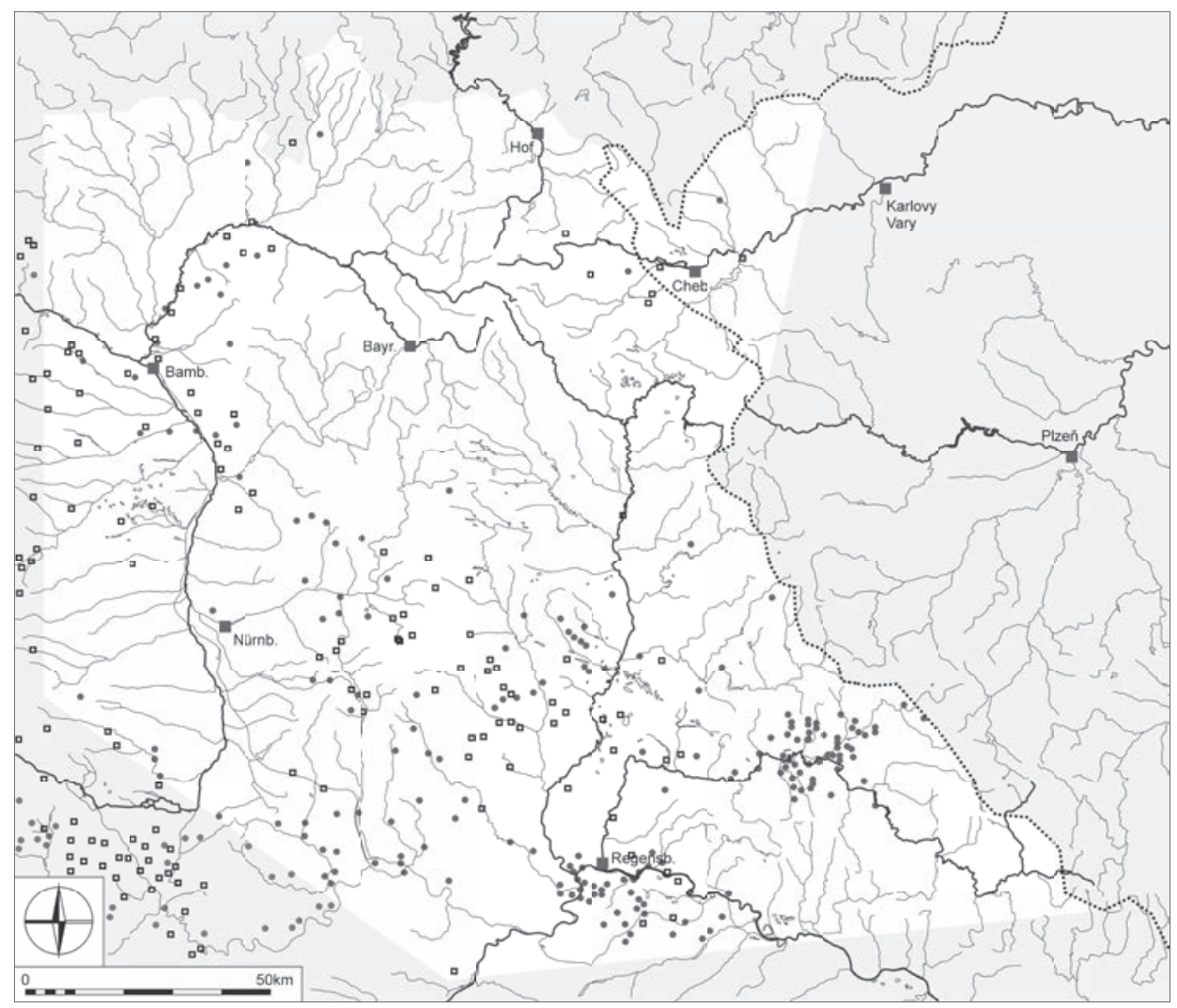

Obr. 6. Archaická německá místní jména s patronymickým sufixem /-ing/ (kruh) a kompozita s /-heim/ (čtverec) v severovýchodním Bavorsku a na Chebsku. Podle Schwarz E. 1960, Deckblatt 1 (vyloučena sekundární místní jména s /-ing/); Schuh 2004, Kartenbeilage 1.

Abb. 6. Archaische deutsche Ortsnamen mit patronymischem Suffix /-ing/ (Kreis) und Komposita mit /-heim/ (Viereck) in Nordostbayern und im Egerland. Nach Schwarz E. 1960, Deckblatt 1 (ausgenommen sekundäre Orstnamen mit /-ing/); Schuh 2004, Kartenbeilage 1. 


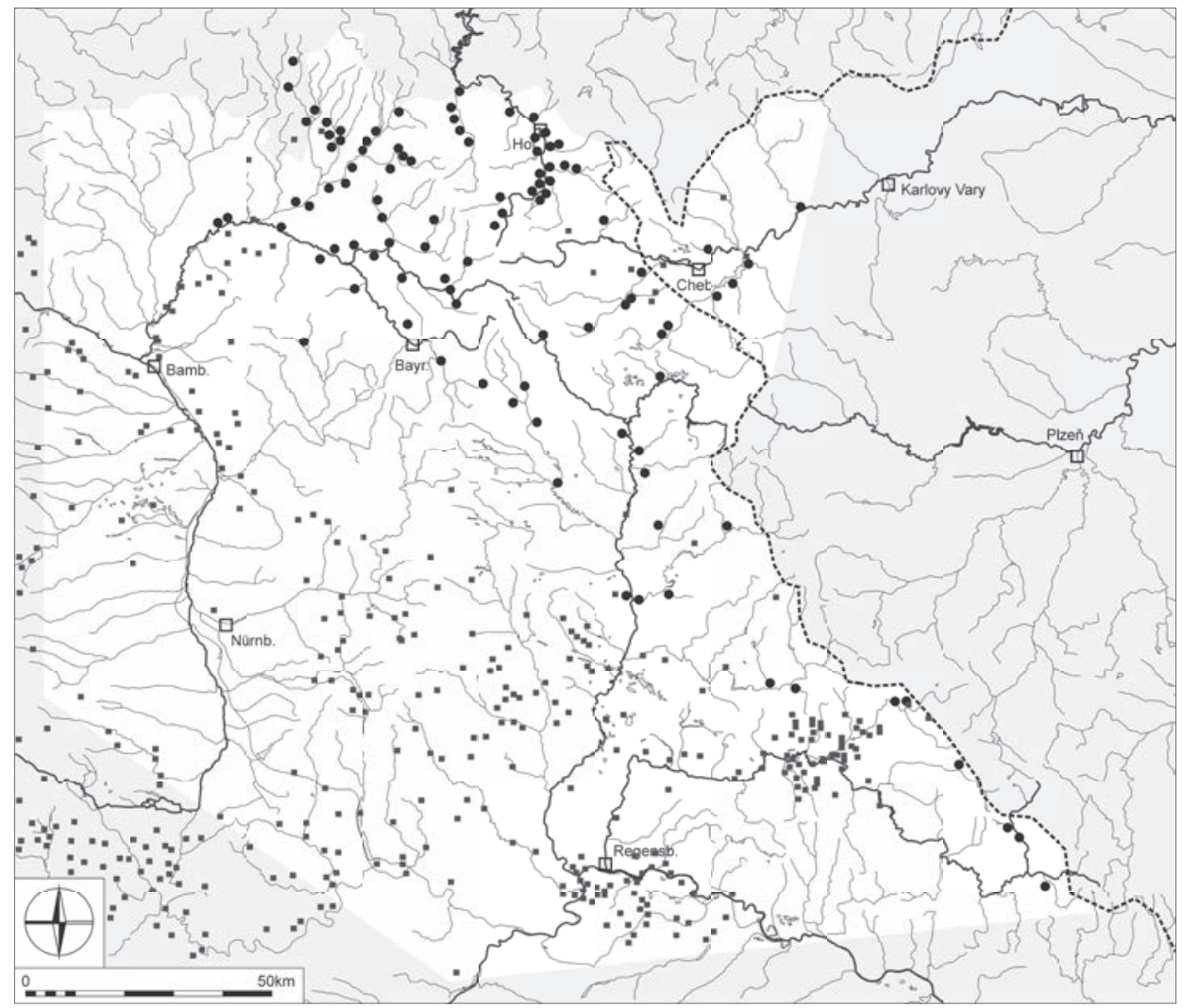

Obr. 7. Slovanská hydronyma (kruh) a archaické typy německých místních jmen s patronymickým sufixem /-ing/a kompozita s /-heim/ (obě čtverec) - srovnání prostorové distribuce v severovýchodním Bavorsku a na Chebsku.

Abb. 7. Slawische Hydronyme (Kreis) und archaische deutsche Ortsnamentypen mit patronymischem Suffix /-ing/ und Komposita mit /-heim/ (beides Viereck) - Vergleich der räumlichen Distribution in Nordostbayern und im Egerland.

\begin{tabular}{|c|c|c|c|c|c|}
\hline & Region - oblast & S & $\mathrm{H}$ & Celkem & H $(\%)$ \\
\hline \multirow{4}{*}{1.} & Regnitz (levobřeží) & 9 & 18 & 27 & 67 \\
\hline & Itz, Mohan po Schney (pravobřežní) & 13 & 16 & 29 & 55 \\
\hline & $\begin{array}{c}\text { Mohan po Weismain (levobřeží), Regnitz } \\
\text { (pravobřeží) }\end{array}$ & 69 & 50 & 119 & 42 \\
\hline & střední Ponábí & 29 & 5 & 34 & 15 \\
\hline \multirow{6}{*}{2.} & povodí Řezné a Koubská pánev & 13 & 17 & 30 & 57 \\
\hline & horní Pomohaní východně od Schney a Weismain & 143 & 29 & 172 & 17 \\
\hline & horní Posálí & 29 & 6 & 35 & 17 \\
\hline & horní Poohří & 61 & 29 & 90 & 32 \\
\hline & horní Ponábí & 67 & 22 & 89 & 25 \\
\hline & Celkem & 433 & 192 & 625 & 31 \\
\hline
\end{tabular}

Tab. 16. Podíl jednoduchých slovanských a jazykově smíšených místních jmen v jednotlivých regionech severovýchodního Bavorska. 1 - oblast bez slovanských hydronym; 2 - oblast se slovanskými hydronymy. S - jednoduchá slovanská místní jména; H - jazykově smíšená (hybridní) místní jména.

Tab. 16. Anteil einfacher slawischer und sprachlich gemischter Ortsnamen in den einzelnen Regionen Nordostbayerns. 1 - Gebiet ohne slawische Hydronyme; 2 - Gebiet mit slawischen Hydronymen. S - einfache slawische Ortsnamen; H - sprachlich gemischte (hybride) Ortsnamen. 


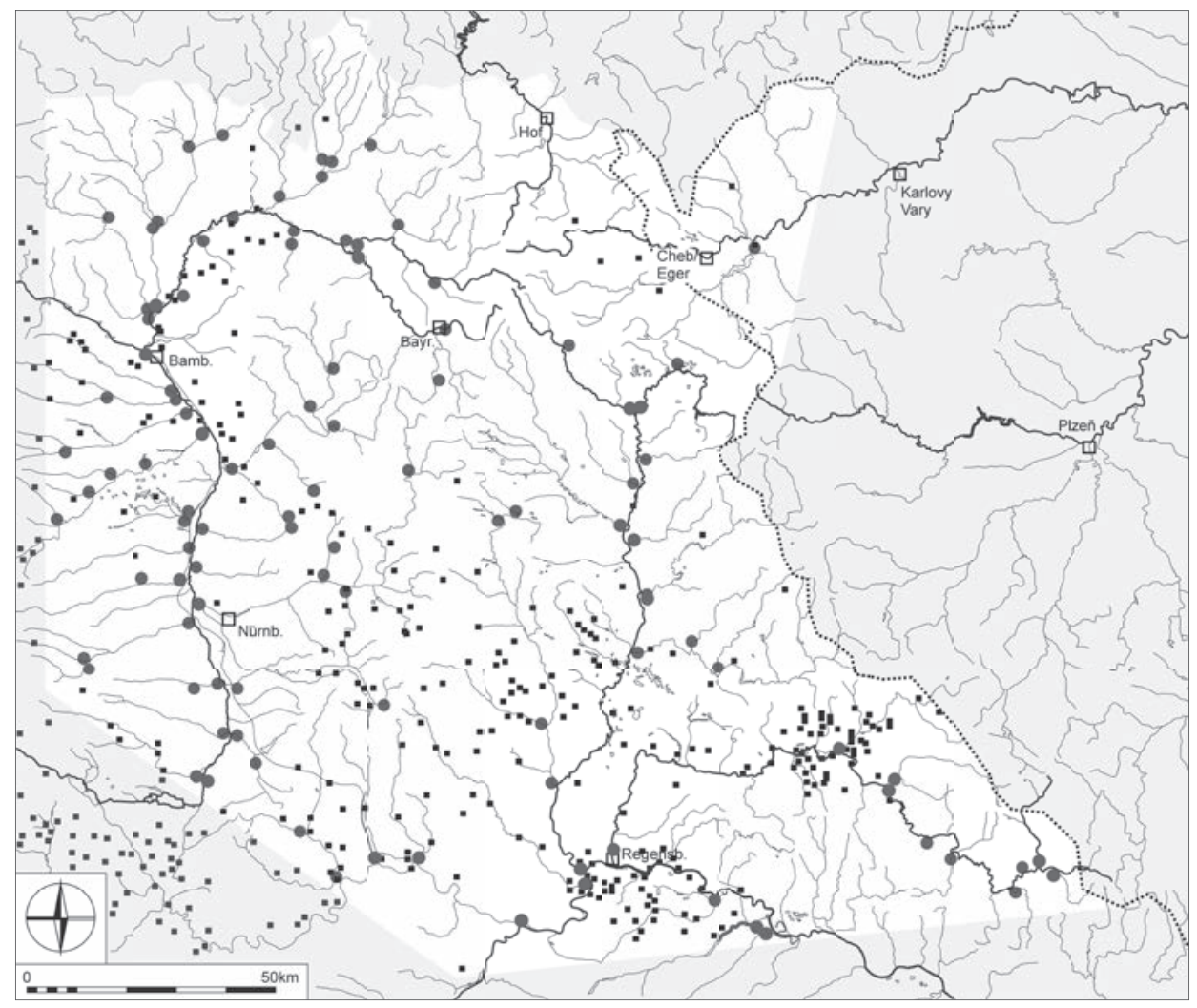

Obr. 8. Předgermánská a germánsko-časně německá hydronyma (kruh), archaické typy německých místních jmen se sufixem /-ing/ a kompozita s /-heim/ (obě čtverec) - srovnání prostorové distribuce v severovýchodním Bavorsku a na Chebsku. Abb. 8. Vorgermanische und germanisch-frühdeutsche Hydronyme (Kreis), archaische deutsche Ortsnamentypen mit Suffix /-ing/ und Komposita mit /-heim/ (beides Viereck) - Vergleich der räumlichen Distribution in Nordostbayern und im Egerland.

Nápadná korelace území bez slovanských hydronym a území, kde významně převažují jazykově smíšená slovansko-německá jména, opět potvrzuje tezi, že k jazykovému kontaktu zde docházelo v důsledku imigrace slovanských mluvčích. Významná část jazykově smíšených jmen zde vznikla spíše v důsledku použití slovanského osobního jména v německé názvotvorbě než $\mathrm{v}$ důsledku integrace staršího slovanského místního jména do němčiny.

Jednoduchá slovanská místní jména a archaické typy německých místních jmen se do velké míry vylučují (obr. 12). To je v souladu s představou, že slovanský jazyk se v severovýchodním Bavorsku šíril v období, kdy archaické typy německých místních jmen již nebyly produktivní. Tam, kde byla německá onymie již vytvořena, mohla se primární slovanská názvotvorba uplatnit jen v malé míře.

\subsection{Vazba na prírodní podmínky}

Dosud prezentovaná kritéria pro určení sociálního kontextu jazykového kontaktu - tedy určení, který jazyk byl mezi venkovskými komunitami primární - lze testovat ještě jedním, tradičně využívaným způsobem. Můžeme posoudit vazbu slovanských místních jmen na regionálně nejpř́iznivější agroklimatické a půdní podmínky. Rozhodující je přitom položení jednoduchých slovanských místních jmen, nikoliv jazykově smíšených. V jednotlivých částech severovýchodního Bavorska lze rozlišit dvě základní situace (srov. Schwarz E. 1960; 1960a, 47; Sage 1996, 215-216; Haberstroh C. ed. 2004, 90-91; Fastnacht 2000, 34*-35*; 2007, 80*; Losert 1993a, 248). 
1) Jednoduchá slovanská místní jména leží v sídelně optimálních částech určitého regionu, tj. v jádru tradičních sídelních komor. Slovanská jednoduchá místní jména zde jsou zpravidla promíšena složenými jmény s /-dorf/, zčásti jmény jazykově smíšenými. V okolních, méně příznivých zónách slovanská místní jména být mohou i nemusí, nebot' obraz mohly lehce deformovat bodově osídlené komunikační koridory. Slovanská toponymie by zde měla být primární, k jazykovému kontaktu došlo později v rámci „conquest“ kontextu.

Slovanskou toponymii v jádru tradičních sídelních komor lze bez výjimky zaznamenat všude tam, kde jsou dodnes evidována slovanská hydronyma. Počátky venkovského osídlení, jazykově nepochybně slovanského, lze datovat podle archeologických nálezů (terminus ad/ante quem). Výběrový přehled pro nejvýznamnější sídelní komory a zóny v severovýchodním Bavorsku a na Chebsku shrnují tabulky 17-18.

2) Jednoduchá slovanská místní jména se sídelně optimálním částem určitého regionu spíše vyhýbají. Neboli sídliště se slovanskými místními jmény lemují obvod tradičních sídelních komor. Tuto situaci lze ve velmi nápadné podobě pozorovat v horním Pomohaní až po ř́ičku Weismain, zvláště pak na horním toku řeky Itz, a dále v povodí řeky Wiesent (Fastnacht 2000, 34-35*; 2007, 80*). Také v podstatné části Horní Falce, ve středním Ponábí a v Koubské pánvi jsou sídliště se slovanskými jmény vysunuta do sídelně méně příznivých částí (Häusler 2004, 87-98). S touto situací všude koresponduje absence slovanských hydronym.

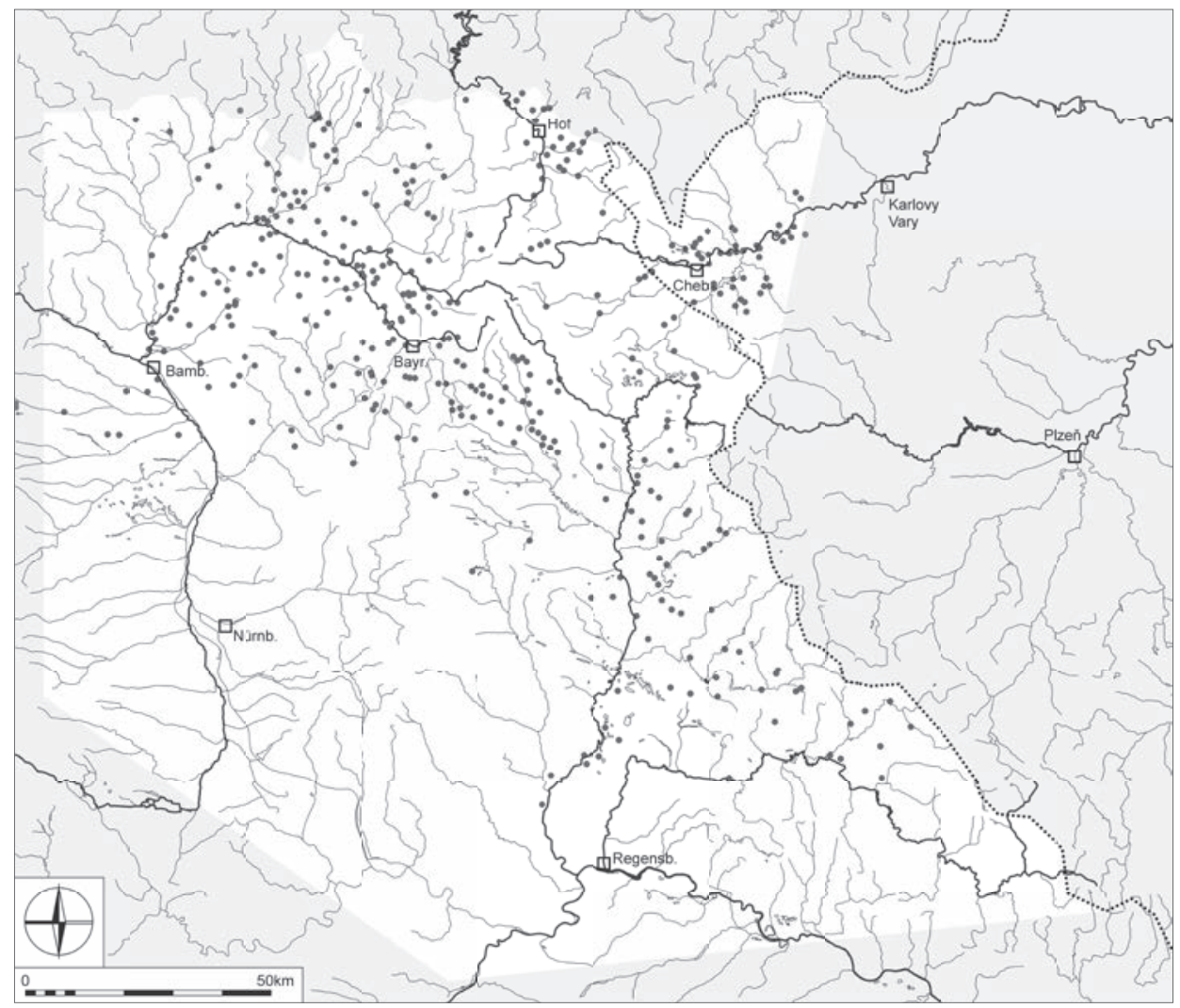

Obr. 9. Jednoduchá slovanská místní jména v severovýchodním Bavorsku a na Chebsku. Vyloučena transonymizovaná, sporná a etymologicky variantní jména. Srov. tab. 13-14.

Abb. 9. Einfache slawische Ortsnamen in Nordostbayern und im Egerland. Ausgenommen transonymisierte, umstrittene und etymologisch variante Namen. Vgl. Tab. 13-14. 


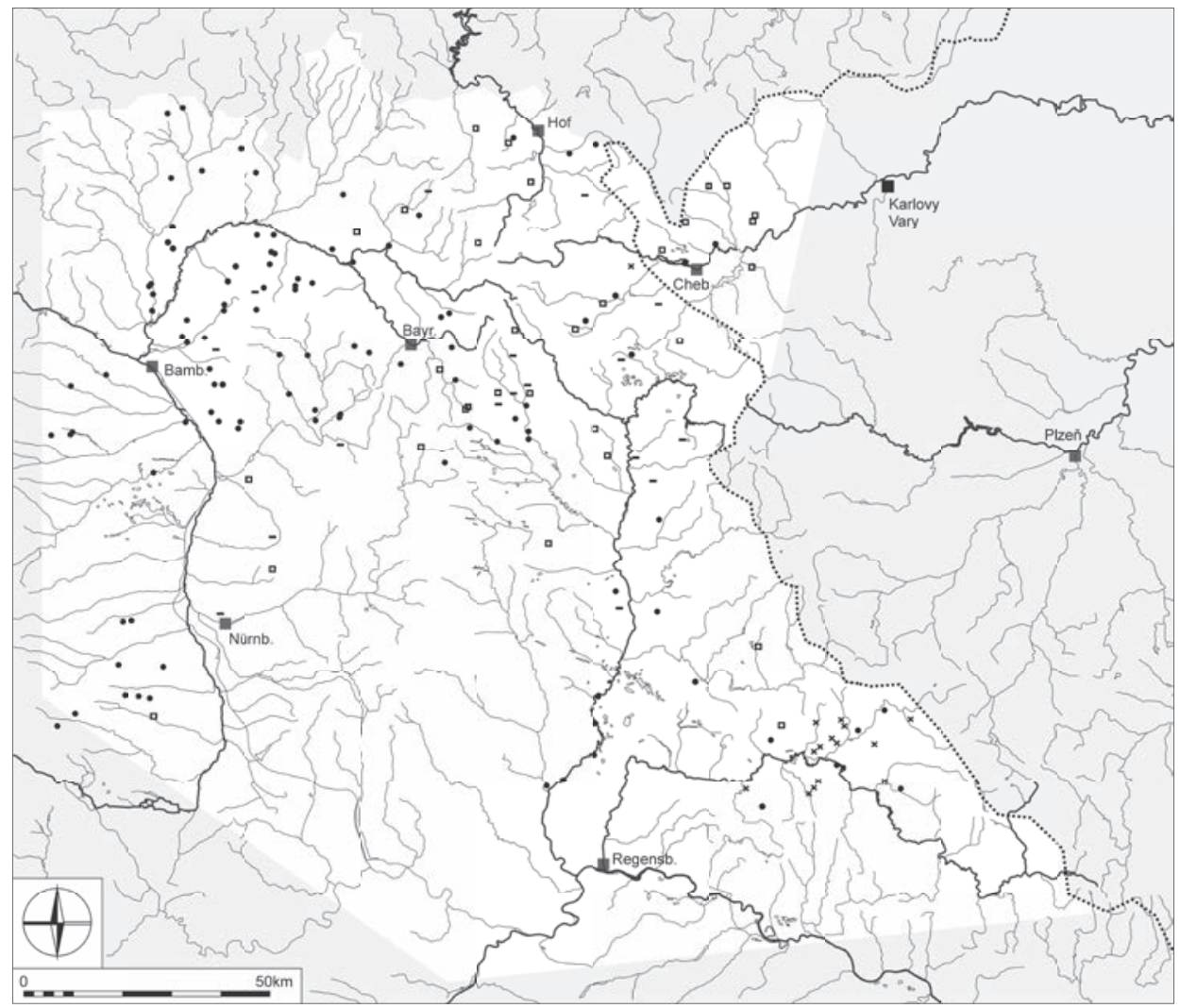

Obr. 10. Jazykově smíšená místní jména v severovýchodním Bavorsku a na Chebsku. Křižek - jména s patronymickým sufixem /-ing/; kruh - kompozita s /-dorf/; čtverec - kompozita s mýtebním základním slovem /-reuth/, /-grün/, popřr. jména s genitivní koncovkou; čára - ostatní (kompozita s/-feld/,/-hof/,/-berg/atd.). Vyloučena transonymizovaná, sporná a etymologicky variantní jména. Srov. tab. 13-14.

Abb. 10. Sprachlich gemischte Ortsnamen in Nordostbayern und im Egerland. Kreuz - Ortsnamen mit patronymischem Suffix/-ing/; Kreis - Komposita mit/-dorf/; Viereck - Komposita mit dem auf Rodung zurückgehenden Grundwort/-reuth/, /-grün/, ggf. Namen mit Genitivendung; Linie - sonstige (Komposita mit/-feld/,/-hof/,/-berg/ etc.). Ausgenommen transonymisierte, umstrittene und etymologisch variante Namen. Vgl. Tab. 13-14.

\begin{tabular}{|c|c|c|}
\hline Hlavní sídelní komora / zóna & Literatura & $\begin{array}{c}\text { Důležité archeologické lokality } \\
\text { 8.-9./10. století }\end{array}$ \\
\hline $\begin{array}{c}\text { „Kasendorfer (Thurnauer) Kleingau“ } \\
\text { centrální sídliště Kasendorf }\end{array}$ & $\begin{array}{c}\text { Herrmann 1982, 272-273; } \\
\text { Winkler 1999, 24-26; Barth 2012, 39-42 }\end{array}$ & $\begin{array}{c}\text { +Kleetzhöfe; +Alladorf; } \text { OKasendorf; } \\
\text { OZultenberg; } \bullet \text { Lochau }\end{array}$ \\
\hline „Melkendorfer Kleingau“ & $\begin{array}{c}\text { Winkler 1999, 24-26; Herrmann E. 1982; } \\
\text { Barth 2012, 42-44 }\end{array}$ & +Grafendobrach \\
\hline „Hummelgau“ & Winkler 1999, 18-22 & $\begin{array}{c}\text { +Gesees; +Mistelgau; } \bullet \text { Mistelgau; } \\
\bullet \text { Obere Culm; }(\bullet \text { Meyernberg) }\end{array}$ \\
\hline
\end{tabular}

Tab. 17. Některé z významných raně středověkých sídelních komor a zón se slovanskými místními jmény. Mikroregiony, kde k jazykovému kontaktu došlo bud'v rámci bilingvního sídelního postupu (imigrační sociální kontext), nebo „conquest“ kontextu (nelze rozlišit). Tradiční vymezení podle hornofrancké historiografie. $(+)$ - pohřebiště; $@$ - hrad; • - sídliště.

Tab. 17. Einige bedeutende frühmittelalterliche Siedlungskammern und-zonen mit slawischen Ortsnamen. Mikroregionen, in denen es entweder im Rahmen eines bilingualen Siedlungsvorgangs (Immigrationskontext) oder eines Kontextes vom Typ „conquest“" zum Sprachkontakt kam (kann nicht unterschieden werden). Traditionelle Abgrenzung gemäß der oberfränkischen Historiographie. (+) - Grabfeld; $\odot$ - Burg; •-Siedlung. 


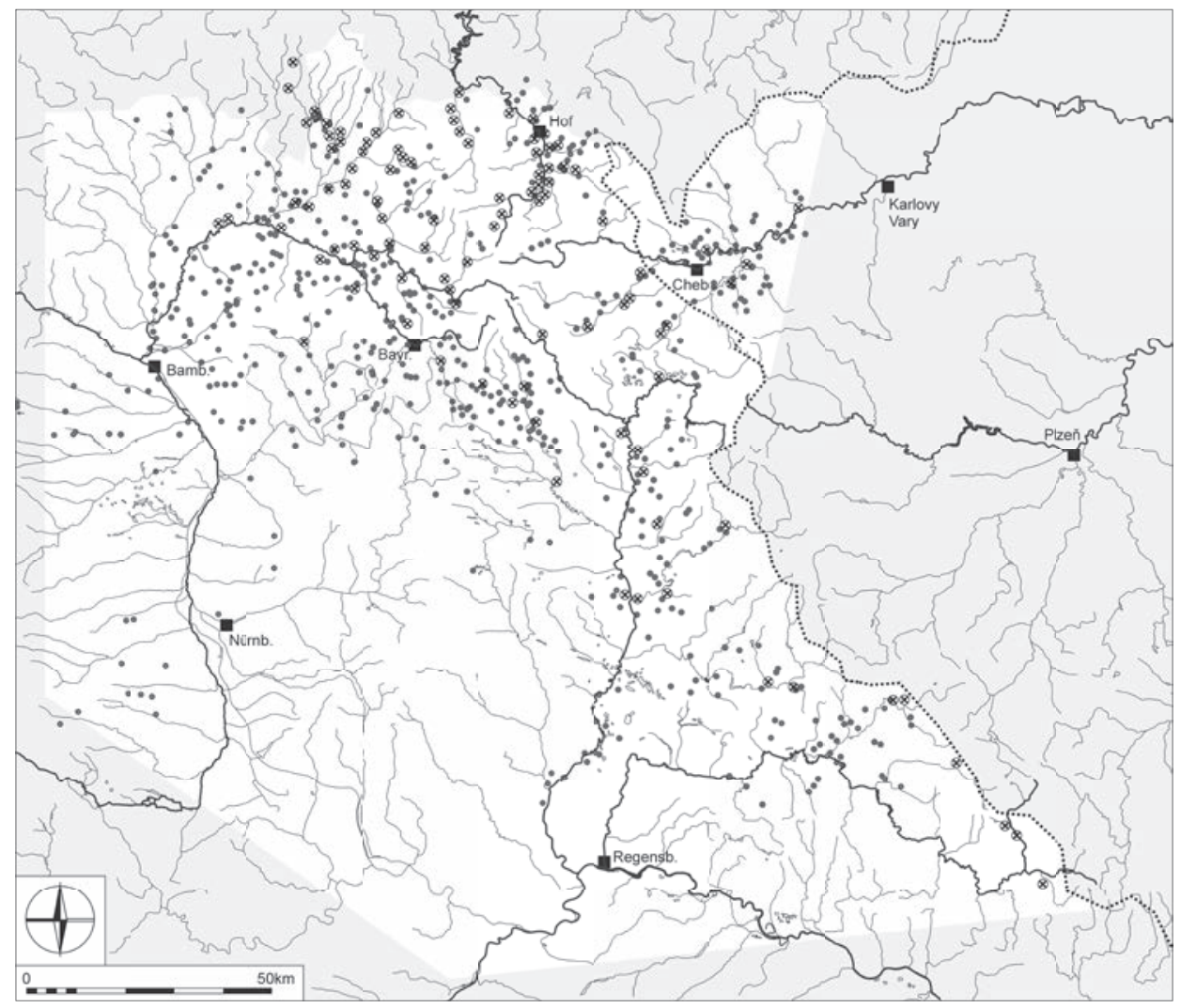

Obr. 11. Slovanská hydronyma (kř́žek v kolečku), jednoduchá slovanská místní jména (kruh) a jazykově smíšená místní jména (kolečko) - srovnání prostorové distribuce v severovýchodním Bavorsku a na Chebsku.

Abb. 11. Slawische Hydronyme (Kreuz im Kreis), einfache slawische Ortsnamen (Kreis) und sprachlich gemischte Ortsnamen (Punkt) - Vergleich der räumlichen Distribution in Nordostbayern und im Egerland.

\begin{tabular}{|c|c|c|c|}
\hline Povodí & Hlavní sídelní komora / zóna & Literatura & $\begin{array}{l}\text { Významné archeologické nálezy } \\
\text { 8.-9. stol. }\end{array}$ \\
\hline Horní Rodach & - & Losert 1993a, 151 & -Friesen-Eichelberg \\
\hline Horní Pomohaní & údolí říčky Trebgast & Winkler 1999, 27; Barth 2012, 44-46 & +Lehen; +Harsdorf; (+Schlömen) \\
\hline Horní Ponábí & $\begin{array}{l}\text { tzv. „Flednitz“, } \\
\text { centrum Rauher Kulm }\end{array}$ & $\begin{array}{l}\text { Losert 2008; } \\
\text { Häusler 2004, 75-76 }\end{array}$ & $\begin{array}{c}\text { CRauher Kulm; +Eichelberg; } \\
\text { +Barbaraberg; +Mockersdorf; } \\
\text { +Wirbenz }\end{array}$ \\
\hline Horní Poohří & Chebská pánev, centrum Cheb & Hejna 1971; Hasil 2010 & $\begin{array}{l}\text { +CCheb; +Třebeň; +Horní Lomany; } \\
\text { •Dolní Lomany; ojedinělé nálezy }\end{array}$ \\
\hline
\end{tabular}

Tab. 18. Významné raně stř̌edověké sídelní komory a zóny, ve kterých jsou zastoupena slovanská hydronyma a jednoduchá místní jména v optimálních sídelních podmínkách. Mikroregiony, kde k jazykovému kontaktu došlo v rámci „conquest“ kontaktu. Podle tradiční hornofrancké, hornofalcké a chebské historiografie. (+) - pohřebiště; $@$ - hrad; • - sídliště.

Tab. 18. Bedeutende frühmittelalterliche Siedlungskammern und-zonen, in denen slawische Hydronyme und einfach Ortsnamen in optimalen Siedlungsbedingungen vertreten sind. Mikroregionen, in denen es im Rahmen eines Kontextes vom Typ „conquest“" zum Sprachkontakt kam. Gemäß der traditionellen oberfränkischen, oberpfälzischen und Egerländer Historiographie. (+) - Gräberfeld; (C) - Burg; •-Siedlung. 


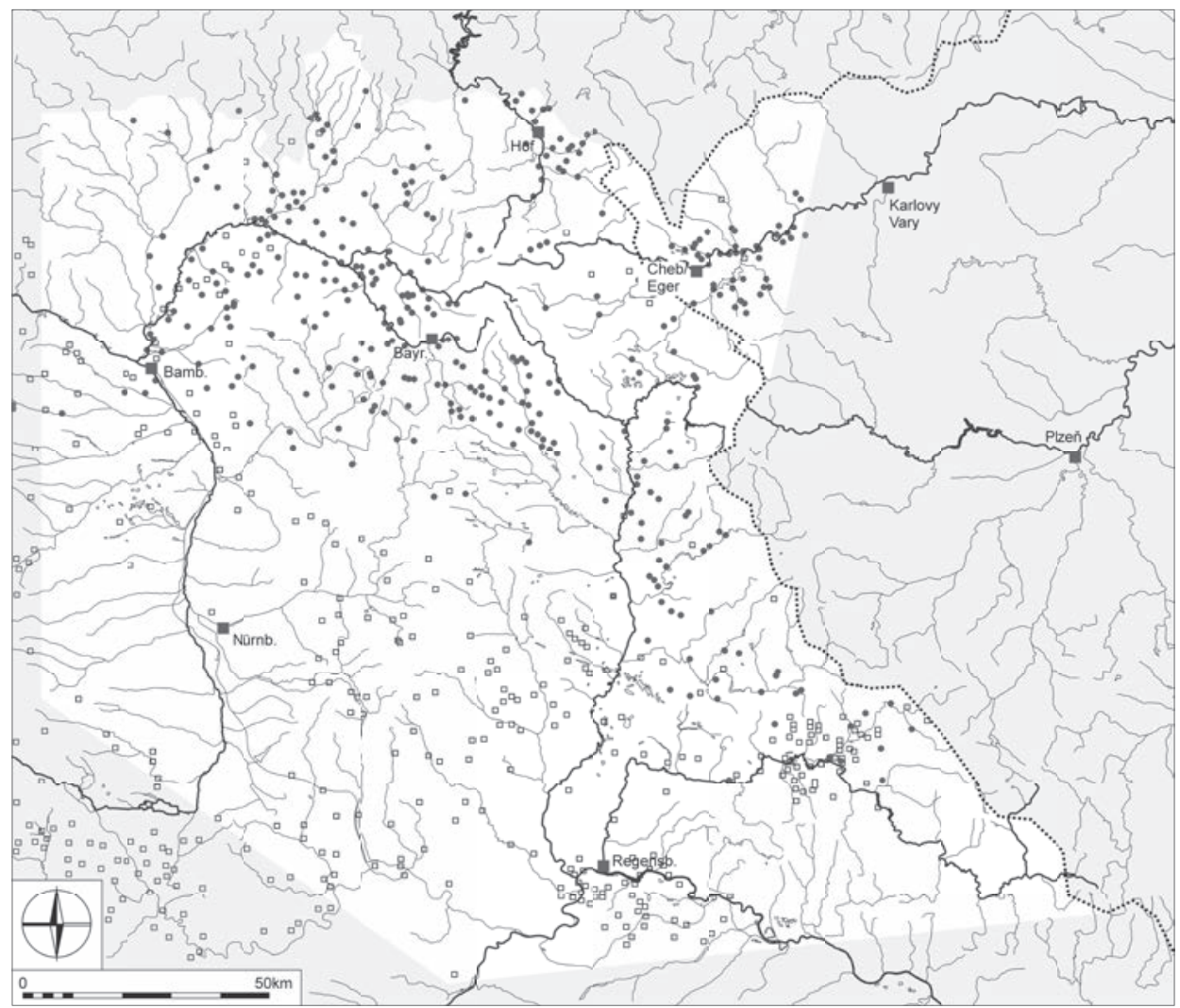

Obr. 12. Srovnání prostorové distribuce archaických typů německých místních jmen a jednoduchých slovanských místních jmen v severovýchodním Bavorsku a na Chebsku. Čtverec - jména se sufixem /-ing/a kompozita s /-heim/; kruh - jednoduchá slovanská jména.

Abb. 12. Vergleich der räumlichen Distribution von archaischen deutschen Ortsnamentypen und einfachen slawischen Ortsnamen in Nordostbayern und im Egerland. Viereck - Namen mit Suffix /-ing/ und Komposita mit /-heim/; Kreis - einfache slawische Namen.

\section{Souhrnné vyhodnocení}

V principu předpokládáme dvě hlavní možné situace. Zaprvé k jazykovému německo-slovanskému kontaktu v severovýchodním Bavorsku došlo v důsledku expanze sociálně minoritního slovanského jazyka (imigrační kontext jazykového kontaktu). Zadruhé v důsledku expanze sociálně dominantního německého jazyka (,conquest“ kontext). V prvém př́ípadě je třeba počítat s migrací nebo transferem slovanských mluvčích, ve druhém případě migrační model není bezpodmínečně nutný. Třetí scénár̆, tj. expanze sociálně dominantního slovanského jazyka, po které následovala expanze sociálně dominantního německého jazyka, není výrazněji indikován, nebot' v severovýchodním Bavorsku a na Chebsku chybí, až na jednu výjimku, slavizovaná předslovanská jména, která by byla zpětně integrována do němčiny.

Toponymické soustavy $\mathrm{v}$ jednotlivých částech severovýchodního Bavorska jsou velmi odlišné. Některé svědčí spíše pro různé formy imigračního, jiné zase „conquest“ kontextu jazykového kontaktu. V rámci přijatelného zobecnění a v souladu s kritérii stanovenými v kapitole 5 můžeme rozlišit níže uvedené situace, které v některých aspektech naznačil již E. Schwarz (1960, 336-362). 


\section{Ia. Klasický imigrační kontext-prolnutí jazyků na jednom teritoriu}

Do tohoto kontextu řadíme jazykově kontaktní oblasti, v jejichž toponymických soustavách se slovanská pojmenování zeměpisných objektů dochovala jen minimálně nebo vůbec ne. Geografické objekty byly zprvu pojmenovány v germánštině/němčině, na jejich základě mohla vznikat paralelní slovanská jména, ale ta později beze stop zanikla. Prostorové vymezení oblastí klasického imigračního kontextu může být v severovýchodním Bavorsku pouze orientační. Jistě tam patří území, kde dominuje „,archaická“ německá toponymie a rozptýlená slovanská toponyma se omezují hlavně na jazykově smíšená místní jména.

Jazykový kontakt v důsledku migrace nebo transferu slovanských mluvčích je v severovýchodním Bavorsku doložen od druhé poloviny 8. století a mohl trvat až do vymizení slovanského jazyka. Oblasti tohoto typu sociálního kontextu jazykového kontaktu byly plošně extrémně rozsáhlé, nebot' $\mathrm{v}$ principu šlo o ty části francké říše, které byly systematicky osídlovány v 8.-12. století a v jejichž blízkosti se nacházely jazykově slovanské oblasti. V severovýchodním Bavorsku sem můžeme řadit Střední a Dolní Franky, jihozápadní část Horních Frank a jih a západ Horní Falce.

\section{Ib. Imigračni kontext s jazykově slovanskými ostrovy}

Takto klasifikujeme ty jazykově kontaktní oblasti, kde se - v detailním měřítku - prolínají doklady klasického imigračního kontextu a „conquest“ kontextu. Neboli slovanská toponymie téměř chybí v sídelně optimální části tradičních sídelních komor, kde jsou zato přítomny archaické typy německých místních jmen, a naopak je výrazná v sídelně méně př́iznivých zónách a komunikačních koridorech s relativně mladším osídlením. Právě v těchto zónách se vytváŕí to, co se nám jeví jako tzv. ,jazykově slovanské ostrovy“. Tento toponymický obraz však nelze interpretovat prrímočaře, nebot' může být kombinovaným výsledkem dvou odlišných jevů - jazykově geografické nebo sociální zonace, ale ty zatím nejsme schopni rozlišit.

Jazykově geografická zonace: rozdíly toponymických soustav jsou dány nerovnoměrným zastoupením slovanského a německého jazyka v rámci venkovských komunit. V předkontaktním období bylo jádro tradičních sídelních komor osídleno jazykově germánsko-německým obyvatelstvem a komunity slovanských mluvčích se začleňovaly do tohoto staršího osídlení, a slovansko-německý jazykový kontakt se zde proto jeví v imigračním kontextu. Nicméně na okrajích těchto tradičních sídelních komor jazykově slovanské komunity osídlily do té doby prázdné enklávy, popř. komunikační koridory.

Sociální zonace: rozdíly plynou z odlišné intenzity, kterou působilo jazykově německé centrum a sociální elity. Neboli němečtí mluvčí mohli kontrolovat názvotvorbu hlavně v jádrech sídelních komor, nikoliv na jejich periferii. Personální sítě slovanských mluvčích mohly být navíc $\mathrm{v}$ jádrech sídelních komor méně stabilní a v důsledku intenzivnější komunikace $\mathrm{s}$ německými sociálně dominantními mluvčími do nich rychleji pronikala němčina. Naopak v periferních mikroregionech byly personální sítě slovanských mluvčích pevné a rezistentní. Zdejší toponymie proto byla utvářena dlouhodobě, nezávisle, a také byla respektována.

Počátky jazykově slovanských komunit lze datovat podle počátků kontinuitního osídlení v jazykově slovanských ostrovech. To většinou začíná až v 8.-9. století. Mezi oblasti, kde se vytvářely jazykově slovanské sídelní komory a zóny, by patřily severní část Horních Frank, střed Horní Falce a oblast Koubské pánve a Všerubské vrchoviny.

\section{Ic. Imigrační kontext jazykového kontaktu - bilingvni sídelní postup}

Tuto situaci můžeme - i když jen mozaikovitě - předpokládat pro ty části severovýchodního Bavorska a Chebska, které byly osídlovány v období, kdy byl slovanský jazyk ještě živý. Výsledkem mohla být velmi torzovitá a rozptýlená slovanská toponymie. Ve větším měřítku a velkoplošně lze bilingvní sídelní postup tohoto typu vložit hlavně na počátek vrcholně středověké 
kolonizace v období 10./11.-12. století, kdy byly plošně osídlovány horské regiony především na severu a východě Horních Frank a Horní Falce, a dále Chebsko.

\section{II. „Conquest“ kontext jazykového kontaktu}

Hlavním kritériem pro vyčlenění oblastí s „conquest“" sociálním kontextem jazykového kontaktu je 1) přítomnost slovanské toponymie na sídelně optimálním území a 2) přítomnost slovanských hydronym. Řadu geografických objektů pojmenovávali primárně slovanští mluvčí a slovanská toponymická soustava ovlivnila podobu později vznikající soustavy německé. Detailnější dělení „,conquest“ kontextu (IIa-IIb) odráží jednak chronologické rozdíly v sídelním postupu a jednak míru centrality a komunikačního významu regionů.

IIa. „Conquest“ kontext s přitomností jazykově germánsko-německých elit nebo agentů dálkových vztahi

Vzdálenější sídelní komory a komunikační koridory byly v severovýchodním Bavorsku, včetně Chebska, dlouhodobě a kontinuitně osídlovány postupně od 8.-9. století, a to obyvatelstvem preferujícím slovanský jazyk. Přítomnost jazykově slovanských elit není na lokální úrovni vyloučena, ale je třeba počítat s jistou mírou vícejazyčnosti. Němečtí mluvčí byli nicméně př́tomni - trvale či periodicky - na centrálních lokalitách, popř. i na venkově. Teoreticky si lze představit, že přítomnost jazykově německých mluvčích v některých sídlech mohla vést k vytváření německých místních jmen bez ohledu na názvotvorbu lokálních rolnických komunit, popr. díky nim mezi venkovskou populaci rychleji pronikala němčina.

Sídelní komory, které mohly být osídleny slovanskými mluvčími již od druhé poloviny 8. století, jsou indikovány mladším horizontem tzv. kostrových pohřebišst karolínsko-otonského období. Jde o sídelně nejpříznivější části východních Horních Frank, severu Horní Falce a Chebska (Klír 2015, 205-211, obr. 8-9).

\section{IIb. Klasický ,conquest“ kontext}

V rámci severovýchodního Bavorska sem lze zařadit pouze horní Posálí, jehož toponymická soustava se neliší od sousední starosrbské oblasti mezi Sálou a Nisou. O reálné moci a zájmu francké, popř. německé, říše na tomto území nejsme př́ímo informováni až do první poloviny 12. století. Nicméně podle historického kontextu nelze o pevné integraci do říšských struktur pochybovat pro 11. století, kdy bylo horní Posálí - at' osídlené či neosídlené - začleněno do bamberského biskupství.

\begin{tabular}{|c|c|}
\hline Kontex & \\
\hline Ia. & $\begin{array}{l}\text { K jazykovému kontaktu docházelo současně ve všech sociálních třídách a jazykových doménách. V jazykově } \\
\text { předkontaktní fázi byl všude zastoupen germánsko-německý jazyk. }\end{array}$ \\
\hline Ib. & $\begin{array}{l}\text { V jádru tradičních sídelních komor došlo k jazykovému kontaktu současně ve všech sociálních třídách a jazykových } \\
\text { doménách. Na části nově osídleného území se ale vytvářely jazykově slovanské sídelní ostrovy, jazykový kontakt se } \\
\text { zde zprvu omezil na jazykovou doménu „moci“ (tj. na komunikaci se sociálními elitami). V jazykově předkontaktním } \\
\text { období mohl být v jádru tradičních sídelních komor zastoupen jazyk germánsko-německý. }\end{array}$ \\
\hline IIa. & $\begin{array}{l}\text { K jazykovému kontaktu zprvu docházelo v jazykové doméně „moci“ a „dálkové vztahy“. Venkovské personální sítě } \\
\text { byly zprvu jazykově slovanské. Jazykově předkontaktní fáze ve společnosti jako celku chybí. }\end{array}$ \\
\hline IIb. & $\begin{array}{l}\text { K jazykovému kontaktu zprvu docházelo v jazykové doméně „moci“ a „dálkové vztahy“. Venkovské personální sítě } \\
\text { byly zprvu jazykově slovanské. Jazykově předkontaktní fáze ve společnosti jako celku chybí. }\end{array}$ \\
\hline III. & $\begin{array}{l}\text { Jazykově předkontaktní fáze chybí. K jazykovému kontaktu docházelo především na úrovni personálních sítí } \\
\text { venkovských komunit. V rámci personálních sítí sociálních elit byl jazykový kontakt již jen marginální. }\end{array}$ \\
\hline
\end{tabular}

Tab. 19. Arény jazykového kontaktu.

Tab. 19. Arenen des Sprachkontaktes. 


\begin{tabular}{|c|c|}
\hline Konte & \\
\hline Ia. & $\begin{array}{l}\text { Slovanský jazyk se v onymii bud’ vůbec neprojevuje, nebo se omezuje hlavně na slovanská osobní jména v jazykově } \\
\text { smíšených jménech, popř. na mikrotoponyma. }\end{array}$ \\
\hline Ib. & $\begin{array}{l}\text { Chybí hydronyma. V jádru tradičních sídelních komor převládají jazykově smíšená jména. Na území jazykově } \\
\text { slovanských ostrovuu, tedy mimo sídelně nejpř́iznivějš̌í části regionu, se vyskytují jednoduchá slovanská místní } \\
\text { a pomístní jména, a také jazykově smišená jména. }\end{array}$ \\
\hline IIa. & Kompletní (včetně hydronym nižšího řádu), zastoupena i v sídelně optimálních částech regionu. \\
\hline IIb. & $\begin{array}{l}\text { Kompletní (včetně hydronym vyššího řádu), zastoupena i v sídelně nejpříznivějších částech regionu; jazykově smíšená } \\
\text { jména s /-dorf/. }\end{array}$ \\
\hline III. & $\begin{array}{l}\text { Nekompletní. Zastoupena jsou především jazykově smíšená jména, zčásti s /-dorf/, zčásti s /-reuth/. Dále jsou } \\
\text { zastoupena jednoduchá slovanská místní jména, často ale vzniklá transonymizací. }\end{array}$ \\
\hline
\end{tabular}

Tab. 20. Slovanská toponymie.

Tab. 20. Slawische Toponymie.

\begin{tabular}{|c|c|}
\hline Kontex & \\
\hline Ia. & $\begin{array}{c}\text { Př́ítomny jsou germánsko-časně německá hydronyma, archaické typy místních jmen a předkolonizační místní jména, } \\
\text { nejčastěji kompozita s/-dorf/. }\end{array}$ \\
\hline Ib. & $\begin{array}{l}\text { Zastoupeny jsou germánsko-časně německá hydronyma, archaické typy místních jmen, předkolonizační místní jména, } \\
\text { nejčastěji kompozita s /-dorf/. Počátky germánsko-německé toponymie lze alespoň hypoteticky datovat do } 8 \text {. století } \\
\text { a hlouběji. }\end{array}$ \\
\hline IIa. & $\begin{array}{l}\text { Zastoupena germánsko-časně německá hydronyma vy̌̌šího řádu (kostra vodní sítě), chybí archaické typy německých } \\
\text { místních jmen, zastoupena předkolonizační a kolonizační německá místní jména, nejčastěji kompozita s /-dorf/. } \\
\text { Doklady přítomnosti německého jazyka se chronologicky zpožd’ují za archeologickými doklady počátkủ osídlení. }\end{array}$ \\
\hline IIb. & $\begin{array}{l}\text { Není kompletní, chybí hydronyma vy̌̌šího řádu. Chybí archaické typy německých místních jmen. Nejčastěji jsou } \\
\text { doložena kompozita s /-dorf/ a kolonizační (tzv. mýtební) místní jména. }\end{array}$ \\
\hline III. & $\begin{array}{l}\text { Kompletní. Zastoupena jsou kompozita s/-dorf/, někde ale dominují typická kolonizační místní jména } \\
\mathrm{s} / \text {-reuth/a /-grün/. }\end{array}$ \\
\hline
\end{tabular}

Tab. 21. Německá toponymie.

Tab. 21. Deutsche Toponymie.

\section{Závěr}

Zde prezentovaná analýza slovansko-německého jazykového kontaktu ve středověkém severovýchodním Bavorsku a na Chebsku využila toho, že šlo o periodu sídelního postupu. To znamená, že toponymické soustavy $\mathrm{v}$ různých regionech vznikaly v rozdílných obdobích, díky čemuž můžeme sledovat chronologické a prostorové proměny jazykových poměrů a sociálního kontextu jazykového kontaktu.

Ke slovansko-německému jazykovému kontaktu v severovýchodním Bavorsku docházelo nejpozději od druhé poloviny 8 . století. Kontrastní rozdíly v podobě toponymických soustav, zejména odlišná prostorová distribuce slovanských hydronym a jednoduchých i smíšených místních jmen, naznačují, že k tomuto kontaktu vedly rozdílné sociální procesy. S tím jde ruku $\mathrm{v}$ ruce výpověd' prostorového rozšíření germánsko-časně německých hydronym a tzv. archaických místních jmen, které poskytují i rámcové chronologické opory. Z pohledu sociolingvistické klasifikace se zdá, že v jedné části severovýchodního Bavorska docházelo k jazykovému kontaktu v imigračním a ve druhé zase v „,conquest“ sociálním kontextu. Obě oblasti se však nemusely radikálně lišit, pokud jde o množství slovanských mluvčích. Rozdíl mohl spočívat i v mnoha dalších, jen obtížně uchopitelných sociálních faktorech, jako byla např. délka trvání a těsnost kontaktu, př́ípadně odlišná míra ekonomické integrace a plánovitosti sídelního postupu.

Podstatným zjištěním je, že germánský a později německý jazyk byl v celé oblasti kontinuitně prrítomen a realizován, i když nerovnoměrně v různých částech společnosti. Na západě a jihu lze počítat s jeho kontinuitou ve všech sociálních třídách a s uplatněním ve všech jazykových doménách. Naopak na severu a východě, včetně Chebska, byla jeho realizace zprvu omezena jen na jazykovou doménu „dálkových vztahů“, popř. i „moci““ (oblast slovanských hydronym).

Pro karolínsko-otonské období nepochybujeme, že komunity preferující slovanský jazyk byly začleňovány do jazykově a etnicky heterogenního sídelního postupu, zčásti snad plánovitě, 
a v toponymii často zanechaly jen malé stopy, převážně v podobě jazykově smíšených místních jmen. Nicméně na okrajích francké říše, které byly sociálně a ekonomicky slaběji kontrolovány a zároveň z nich vycházely komunikačními koridory směřující do jazykově slovanských oblastí, se během sídelního postupu vytvářela poměrně výrazná a někdy i téměř úplná slovanská toponymie, která zahrnovala také hydronymii toků vyššího řádu (9.-12. století). Teoreticky si lze představit i vyšší sociální status slovanského jazyka a respektování slovanské názvotvorby franckými elitami. Rozdíly mezi slovanskými a německými mluvčími přitom není třeba vidět ostře a staticky, nebot' jen málo víme o tom, jak se na šíření a uplatnění jednoho z jazyků mohla podílet etnicita. Lze si představit, že kontaktní situace vytvářela poměrně komplikované sociální prostředí charakterizované mobilními a široce propojenými komunitami, ve kterých mohla být dlouhodobě preferována i etnicita slovanská, vytvářející předpoklady pro příslušné jazykové profilování původně jinak heterogenní populace (např. Pohl 2000, 11). Jednotlivé komunity by pak nebyly pasivními nositeli jednoho z jazyků, ale v rámci volby by ho využívaly jako sociální (etnifikující) nástroj.

Předkládaná studie prezentuje dosud jen málo využité poznávací možnosti, které leží na průsečíku lingvistiky, archeologie a historie. Metodický postup a výsledky zároveň nabízí k další diskusi a ke konfrontaci se situací nejen v sousedních oblastech, jako jsou Durynsko (Gringmuth-Dallmer 1983), Čechy (Schwarz E. 1961) a bavorsko-rakouské Podunají, ale vůbec na celém území, kde byla slovanština v minulosti v kontaktu s jinými jazyky (Boček 2014, 263-380).

Tato studie vznikla v rámci výzkumného projektu GPP405/12/P715 - „Vesnická sídliště v Čechách v období pozdně středověkých a raně novověkých proměn“ (postdoktorský projekt GA ČR). Za podnětné komentáře k textu děkuji Dr. Wolfgangu Jankovi (Řezno), prof. Karlheinzi Hengstovi (Chemnitz), Dr. Christianu Zschieschangovi (Lipsko), Dr. Vítu Bočkovi (Brno) a Dr. Milanu Harvalíkovi (Praha).

Pokud není uvedeno jinak, tabulky a obrázky sestavil autor.

\section{Literatura}

ANDRASCHKE, J., 2007: Germanische Siedlungsnamen. In: Missionierung und Christianisierung im Regnitz- und Obermaingebiet. Historischer Verein Bamberg, Schriftenreihe 41 (Bergmann et al., edd.), 217-228. Bamberg.

ASH, S., 2006: Social Class. In: The Handbook of Language Variation and Change. Blackwell Handbooks in linguistics (Chambers, J. K.-Trudgill, P.-Schilling-Estes, N., edd.), 402-422. Oxford. 3rd edition.

BACH, A., 1953/54: Deutsche Namenkunde II. Die deutschen Ortsnamen 1. Einleitung. Zur Laut- und Formanlehre, zur Satzfügung, Wortbildung und -bedeutung der deutschen Ortsnamen (1953). Die Deutsche Ortsnamen 2. Die deutschen Ortsnamen in geschichtlicher, geographischer, soziologischer und psychologischer Betrachtung. Ortsnamenforschung im Dienste anderer Wissenschaften (1954). Grundriss der germanischen Philologie 18. Heidelberg 1953.

BACHMANN, M., 1926: Die Verbreitung der slavischen Siedlungen in Nordbayern. Erlangen.

BERGER, T., 1991/1992: Tschechische Bezeichnungen für ausländische Ortsnamen mit besonderer Berücksichtigung von Bayern, Blätter für oberdeutsche Namenforschung 28/29, 77-122.

BERGMANN, R. et al., edd., 2007: Missionierung und Christianisierung im Regnitz- und Obermaingebiet. Historischer Verein Bamberg, Schriftenreihe 41. Bamberg.

BESSE, M., 2000: Toponymische Namenpaare in Sprachgrenzzonen, Namenkundliche Informationen $77 / 78,13-39$.

BILY, I., 2000: Einleitung. In: Atlas altsorbischer Ortsnamentypen. Studien zu toponymischen Arealen des altsorbischen Gebietes im westslawischen Raum. Heft 1 (Eichler, E., ed.), 9-43. Stuttgart.

- 2000a: Literatur zum Atlas altsorbischer Grundformen. In: Atlas altsorbischer Ortsnamentypen. Studien zu toponymischen Arealen des altsorbischen Gebietes im westslawischen Raum. Heft 1 (Eichler, E., ed.), 50-97. Stuttgart.

BOČEK, V., 2014: Praslovanština a jazykový kontakt - Proto-Slavonic and Language Contact. Praha.

BRATHER, S., 2004: Ethnische Interpretationen in der Frühgeschichtlichen Archäologie. Geschichte, Grundlagen und Alternativen. Ergänzungsbände zum Reallexikon der Germanischen Altertumskunde 42. Berlin - New York. 
- 2006: Jednorodność przybyszów czy zróżnicowanie regionów? In: Nie-Słowianie o początkach Słowian. Mała Biblioteka 18 (Urbańczyk, P., ed.), 57-87. Poznań - Warszawa.

CONDE-SILVESTRE, J. C.-PÉREZ-RAJA, D., 2011: Multilingualism, Social Network Theory, and Linguistic Change in the Transition from Old to Middle English. In: Conceptualizing multilingualism in medieval England, c. 800-c. 1250. Studies in the Early Middle Ages 27 (Tyler, E. M., ed.), 239-254. Turnhout.

CURTA, F., 2008: Utváření Slovanů (se zvláštním zřetelem k Čechám a Moravě) - The making of the Slavs (with a special emphasis on Bohemia and Moravia), AR LX, 643-694.

CURTA, F., ed., 2005: Borders, Barriers, and Ethnogenesis. Frontiers in Late Antiquity and the Middle Ages. Studies in the Early Middle Ages 12. Turnhout.

ČORNEJOVÁ, M., 2009: Tvoření nejstarších českých místních jmen. Bohemika z 11.-13. století. Spisy Masarykovy univerzity v Brně 383. Brno.

DEBUS, F., 2012: Namenkunde und Namengeschichte. Eine Einführung. Berlin.

DEBUS, F.-SCHMITZ, H. G., 2004: Schichten vordeutscher Namen im deutschen Sprachgebiet. In: Sprachgeschichte. Ein Handbuch zur Geschichte der deutschen Sprache und ihrer Erforschung 2. Handbücher zur Sprach- und Kommunikationswissenschaft (Besch, W.-Reichmann, O.-Sonderegger, S., edd.), 2088-2095. Berlin. 2. Auflage.

DEUMERT, A., 2011: Multilingualism. In: The Cambridge Handbook of Sociolinguistics (Mehstrie, R., ed.), 261-282. Cambridge.

EICHLER, E., 1962: Zur Etymologie und Struktur der slawischen Orts- und Flußnamen in Nordostbayern, Wissenschaftliche Zeitschrift der Karl-Marx-Universität Leipzig, Gesellschafts- und Sprachwissenschaftliche Reihe 11, 365-395.

- 1963: Zur Geographie und Chronologie der slawischen Namen in Nordostbayern, Veröffentlichungen des Instituts für Slawistik der Akademie der Wissenschaften Berlin 29, 81-87.

- 1999: Zur sprachgeschichtlichen Stellung des Bayernslavischen. In: Festschrift für Klaus Trost zum 65. Geburtstag. Die Welt der Slaven. Sammelbände 5 (Hansack, E.-Koschmal, W.-Nübler, N.-Večerka, R., edd.), 57-62. München.

- 2007: Slavische Siedlungsnamen. In: Missionierung und Christianisierung im Regnitz- und Obermaingebiet. Historischer Verein Bamberg, Schriftenreihe 41 (Bergmann et al., edd.), 229-236. Bamberg.

EICHLER, E., ed., 2000/2004: Atlas altsorbischer Ortsnamentypen. Studien zu toponymischen Arealen des altsorbischen Gebietes im westslawischen Sprachraum. Heft 1-5. Leipzig.

EICHLER, E. et al., edd., 1995/1996: Namenforschung - Name Studies - Les noms propres. Ein internationales Handbuch zur Onomastik - An International Handbook of Onomastics - Manuel international d'onomastique. Bd. 1-3. Handbücher zur Sprach- und Kommunikationswissenschaft / Handbooks of Linguistics and Communication Science 11/1-3. Berlin - New York.

EICHLER, E. et al., edd., 2001: Beiträge zur slavisch-deutschen Sprachkontaktforschung. I: Siedlungsnamen im oberfränkischen Stadt- und Landkreis Bamberg. Slavica. Monographien, Hand-, Lehr- und Wörterbücher 2. Heidelberg.

- 2006: Beiträge zur slavisch-deutschen Sprachkontaktforschung. I: Siedlungsnamen im oberfränkischen Stadt- und Landkreis Bamberg. Slavica. Monographien, Hand-, Lehr- und Wörterbücher 4. Heidelberg.

ENDRES, R., 2003: Slawen in Franken, Bericht des Historischen Vereins für die Pflege der Geschichte des ehemaligen Fürstbistums Bamberg 139, 25-38.

ETTEL, P., 2001: Karlburg - Roßtal - Oberammerthal. Studien zum frühmittelalterlichen Burgenbau in Nordbayern: Grabungen des Bayerischen Landesamtes für Denkmalpflege (Bd. 1-3). Frühgeschichtliche und provinzialrömische Archäologie 5, Veröffentlichung der Kommission zur Vergleichenden Archäologie Römischer Alpen- und Donauländer. Rahden/Westf.

FASTNACHT, D., 2000: Ebermannstadt. Ehemaliger Landkreis Ebermannstadt. Historisches Ortsnamenbuch von Bayern. Oberfranken 4. München.

- 2007: Staffelstein. Ehemaliger Landkreis Staffelstein. Historisches Ortsnamenbuch von Bayern. Oberfranken 5. München.

FISHMAN, J., 1972: The sociology of language; an interdisciplinary social science approach to language in society. Rowley.

FISCHER, R., 1940: Zur Namenkunde des Egerlandes. Die slawischen Ortsnamen des Egerlandes und ihre Auswertung für die Lautlehre und Siedlungsgeschichte. Forschungen zur sudetendeutschen Heimatkunde. Allgemeine Reihe 9. Reichenberg - Leipzig.

FRANK, H.-OELWEIN, C.-SCHUH, R., 2002: Sulzbach-Rosenberg. Ehemaliger Landkreis Sulzbach-Rosenberg. Historisches Ortsnamenbuch von Bayern. Oberpfalz 2. München.

GEORGE, D., 2008: Lichtenfels. Ehemaliger Landkreis Lichtenfels. Historisches Ortsnamenbuch von Bayern. Oberfranken 6. München. 
GIESLER, J., 1997: Der Ostalpenraum vom 8. bis 11. Jahrhundert. Studien zu archäologischen und schriftlichen Zeugnissen. Teil 2. Historische Interpretation. Frühgeschichtliche und provinzialrömische Archäologie 1. Rahden/Westf.

GREULE, A., 2014: Deutsches Gewässernamenbuch. Etymologie der Gewässernamen und der dazugehörigen Gebiets-, Siedlungs- und Flurnamen. Berlin - Boston 2014.

GRINGMUTH-DALLMER, E., 1983: Die Entwicklung der frühgeschichtlichen Kulturlandschaft auf dem Territorium der DDR unter besonderer Berücksichtigung der Siedlungsgebiete. Schriften zur Ur- und Frühgeschichte 35. Berlin.

GUTTENBERG, E., 1927: Die Territorienbildung am Obermain. I. und II. Teil. Berichte über Bestand und Wirken des Historischen Vereins zu Bamberg 79, I-XVII, 1-539.

GÜTTER, A., 1989: Germanisch-frühdeutsche Ortsnamen im Oberegergebiet, vor allem im Bereich um Thiersheim - Arzberg - Schirnding, Archiv für Geschichte von Oberfranken 69, 40-48.

GUY, G. R., 2011: Language, social class and status. In: The Cambridge Handbook of Sociolinguistics (Mehstrie, R., ed.), 159-185. Cambridge.

HABERSTROH, C., ed., 2004: Das frühmittelalterliche Gräberfeld von Wirbenz, Gde. Speichersdorf. Kataloge der archäologischen Staatssammlung 30. München.

HABERSTROH, J., 2000: Germanische Funde der Kaiser- und Völkerwanderungszeit aus Oberfranken. Materialhefte zur bayerischen Vorgeschichte. Reihe A - Fundinventare und Ausgrabungsbefunde. Kallmünz / Opf.

HARNISCH, F., 1983: Die Erforschung der norbairischen Mundart von den Anfängen bis 1980. Eine forschungsgeschichtliche Bestandsaufnahme mit annotierter Bibliographie. Zeitschrift für Dialektologie und Linguistik, Beihefte 43. Stuttgart.

HASIL, J., 2010: Raně středověké osídlení Chebska - The Early Medieval Settlement of the Cheb Region, Studia Mediaevalia Pragensia 9, 7-73.

HÄUSLER, I., 2004: Der Beitrag des slavischen Siedlungsträgers zur Raumerschließung in der Oberpfalz eine historisch-geographische Analyse. In: Regensburger Beiträge zur Regionalgeographie und Raumplanung 9 (Ehrig, R.-Manske, D. J.-Werner, E., edd.), 1-175. Regensburg.

HEJNA, A., 1971: Archeologický výzkum a počátky sídlištního vývoje Chebu a Chebska-Die archäologische Forschung und ihre Bedeutung für die Frage der Siedlungsentwicklung in Eger und dem Egerlande im frühen und hohen Mittelalter, PA LXII, 488-550.

HENGST, K., 1996: Namen in Sprachaustausch. Slavisch. In: Namenforschung - Name Studies - Les noms propres. Ein internationales Handbuch zur Onomastik - An International Handbook of Onomastics Manuel international d'onomastique. Bd. 1-3. Handbücher zur Sprach- und Kommunikationswissenschaft /Handbooks of Linguistics and Communication Science 11/1-3 (Eichler et al., edd.), 1007-1011. Berlin - New York.

- 1999: Beiträge zum slavisch-deutschen Sprachkontakt in Sachsen und Thüringen (Dahmen, W.-Eichler, E.Kramer, J., edd.). Veitshöchheim bei Würzburg.

HENSCH, M., 2011: Territory, Power and Settlement. Observations on the Origins of Settlement around the Early Medieval Power Sites of Lauterhofen and Sulzbach in the Upper Palatinate. In: Frühgeschichtliche Zentralorte in Mitteleuropa. Studien zur Archäologie Europas 14 (Henning, J.-Leube, A.-Biermann, F., edd.), 479-518. Bonn.

HERRMANN, E., 1965: Slawisch-germanische Beziehungen im südostdeutschen Raum von der Spätantike bis zum Ungarnsturm. Ein Quellenbuch mit Erläuterungen. Veröffentlichungen des Collegium Carolinum 17. München.

- 1982: Zur Siedlungsgeschichte des Kulmbacher Landes, Zeitschrift für Bayerische Landesgeschichte 45, 259-297.

HICKEY, R., ed., 2010: The Handbook of Language Contact. Blackwell Handbooks in Linguistics. Chichester.

CHAMBERS, J. K.-SCHILLING-ESTES, N., edd., 2013: The Handbook of Language Variation and Change. Blackwell Handbooks in linguistics. Chichester. 2nd edition.

JAKOB, H., 1982: Der Klotzgau - ein slawischer Kleingau am Rande der Fränkischen Alb, Zeitschrift für Archäologie 16, 95-112.

JANKA, W., 2003: Zur Problematik der „slavisch-deutschen Mischnamen“ in Nordbayern. In: Namen in Grenzregionen. Tagungsband des internationalen onomastischen Symposiums in Klingenthal / Elsass (7.-11. 5. 2001). Beihefte zur Österreichischen Namenforschung 3 (Anreiter, P.-Plangg, G., edd.), 33-41. Klagenfurt.

KLÍR, T., 2015: Hydronymie Chebska v kontextu severovýchodního Bavorska. K otázce jazykových poměrů v raném středověku - The Hydronymy of the Cheb District in the Context of Northeast Bavaria: On the question of the language situation in the Early Middle Ages, Praehistorica 32/2, 173-223. 
- v tisku: Social Context of the Slavic-German language contact. North-eastern Bavaria and the Eger region in the Early Middle Ages. In: Beiträge zur Frühgeschichte und zum Mittelalter Ostthüringens 7. Langweissbach.

KRANZMAYER, E., 1956: Historische Lautgeographie des gesamtbairischen Dialektraumes. Wien.

LOSERT, H., 1993: Die früh- bis hochmittelalterliche Keramik in Oberfranken. Zeitschrift für Archäologie des Mittelalters, Beiheft 8. Bonn.

- 1993a: Die slawische Besiedlung Nordostbayerns aus archäologischer Sicht. In: Vorträge des 11. Niederbayerischen Archäologentages, 207-270. Rahden/Westf.

- 2008: Archäologische Untersuchungen am Rauhen Kulm in der Flednitz. In: Kemnath. 1000 Jahre... und mehr (Neubauer, M.-Schön, R.-Thieser, B., edd.), 65-87. Pressath.

- 2009: Moinvinidi, Radanzvinidi und Nabavinida. Geschichte und Archäologie der Slawen in Bayern. In: Siedlungsstrukturen und Burgen im westslawischen Raum. Beiträge der Sektion zur slawischen Frühgeschichte der 17. Jahrestagung des Mittel- und Ostdeutschen Verbandes für Altertunmsforschung in Halle an der Saale, 19. bis 21. März 2007. Beiträge zur Ur- und Frühgeschichte Mitteleuropas 52 (Biermann, F., ed.), 219-294. Langenweissbach.

MACHILEK, F., 2007: Besitz- und Herrschaftsgeschichte. In: Missionierung und Christianisierung im Regnitz- und Obermaingebiet. Historischer Verein Bamberg, Schriftenreihe 41 (Bergmann et al., edd.), 283-294. Bamberg.

MERZ, J.-SCHUH, R., edd., 2004: Franken im Mittelalter. Francia orientalis, Franconia, Land zu Franken. Raum und Geschichte. Hefte zur bayerischen Landesgeschichte. Darmstadt.

MESTHRIE, R., ed., 2011: The Cambridge Handbook of Sociolinguistics. Cambridge Handbooks in Language and Linguistics. Cambridge.

MILROY, L.-GORDON, M., edd., 2003: Sociolinguistics. Method and Interpretation. Language in society 34. Oxford.

MILROY, L., 2006: Social Networks. In: The Handbook of Language Variation and Change, Blackwell Handbooks in linguistics (Chambers, J. K.-Trudgill, P.-Schilling-Estes, N., edd.), 549-572. Oxford. 3rd edition.

PLEINTINGER, A., 2008: Die Gewässernamen im Bereich der oberen Eger. Eine onomastische Untersuchung. München.

POHL, W., 2001: Soziale Grenzen und Spielräume der Macht. In: Grenze und Differenz im frühen Mittelalter, Forschungen zur Geschichte des Mittelalters 1 (Pohl, W.-Reimitz, H., edd.), 11-18. Wien.

POHL, W.-REIMITZ, H., edd., 2000: Grenze und Differenz im frühen Mittelalter. Forschungen zur Geschichte des Mittelalters 1. Wien.

POHL, W.-ZELLER, B., edd., 2012: Sprache und Identität im frühen Mittelalter. Forschungen zur Geschichte des Mittelalters 20. Wien.

POKORNY, S., 2005: Der Gewässername Creußen. In: Gewässernamen in Bayern und Österreich. 3. Kolloquium des Arbeitskrieses für bayerisch-österreichische Namenforschung, Regensburg, 17./28. Februar 2004 (Greule, A., ed.), 123-136. Regensburg.

PÖLLATH, R., 2002: Karolingerzeitliche Gräberfelder in Nordostbayern. Eine archäologisch-historische Interpretation mit der Vorlage der Ausgrabungen von K. Schwarz in Weismain und Thurnau-Alladorf. I (= Text), II (= Abbildungen, Listen, Literatur), III (= Katalog), IV (= Tafeln). München.

ROELCKE, T., 1995: Periodisierung der deutschen Sprachgeschichte. Analysen und Tabellen. Studia Linguistica Germanica 40. Berlin - New York.

ROMAINE, S., 2010: Contact and Language Death. In: The Handbook of Language Contact, Blackwell Handbooks in Linguistics (Hickey, R., ed.), 321-339. Chichester.

ROWLEY, A. R., 1997: Morphologische Systeme der nordostbayerischen Mundarten in ihrer sprachgeographischen Verflechtung. Zeitschrift für Dialektologie und Linguistik, Beihefte 93. Stuttgart.

SAGE, W., 1996: Frühgeschichte und Frühmittelalter. In: Oberfranken in vor- und frühgeschichtlicher Zeit (Sage, W.-Abels, B.-U.-Züchner, Ch., edd.), 161-280. Bayreuth. 2. Auflage.

SANKOFF, G., 2006: Linguistic Outcomes of Language Contact. In: The Handbook of Language Variation and Change, Blackwell Handbooks in Linguistics (Chambers, J. K.-Trudgill, P.-Schilling-Estes, N., edd.), 638-668. Malden - Oxford - Carlton. 3rd edition.

SCHMALE, F.-J.-STÖRMER, W., 1997: Die politische Entwicklung bis zur Eingliederung ins Merowingische Reich. In: Handbuch der bayerischen Geschichte III/1. Geschichte Frankens bis zum Ausgang des 18. Jahrhunderts (Spindler, M., ed.). München. 3. Aufl.

- 1998: Frühmittelalterliche Ortsnamen zwischen Main und Steigerwald. In: Das Land zwischen Main und Steigerwald im Mittelalter. Die auf dem Symposion in Castell vom 5. bis 7. September 1996 gehaltenen Vorträge, Erlanger Forschungen A, 79 (Wenderhorst, A., ed.), 21-67. Erlangen. 
SCHUH, R., 2004: Die germanisch-deutsche und slawische Besiedlung Frankens im Lichte der Ortsnamen. In: Franken im Mittelalter. Francia orientalis, Franconia, Land zu Franken. Raum und Geschichte (Merz, J.-Schuh, R., edd.), 25-51. München.

SCHÜTZ, J., 1994: Frankens mainwendische Namen. Geschichte und Gegenwart. München.

SCHWARZ, E., 1953: Die ing-Namen des Chamer Beckens, Beiträge zur Namenforschung 4, $291-324$.

- 1960: Sprache und Siedlung in Nordostbayern. Erlanger Beiträge zur Sprach- und Kunstwissenschaft 4. Erlangen.

- 1960a: Deutsch-slawische Namensbeziehungen von der Ostsee bis zur Adria. In: VI. Internationaler Kongreß für Namenforschung 1. Studia onomastica monacensia 2, 29-56. München.

- 1961: Die Ortsnamen der Sudetenländer als Geschichtsquelle. Handbuch der sudetendeutschen Kulturgeschichte 1. München. 2. Auflage.

- 1984: Frühmittelalterlicher Landesausbau im östlichen Franken zwischen Steigerwald, Frankenwald und Oberpfälzer Wald. RGZM Monographien 5. Mainz.

SPERBER, R., 1970: Das Flußgebiet des Mains. Hydronymia Germaniæ A 7. Wiesbaden.

STEGER, H., 1968: Sprachraumbildung und Landesgeschichte im östlichen Franken: das Lautsystem der Mundarten im Ostteil Frankens und seine sprach- und landesgeschichtlichen Grundlagen. Schriften des Instituts für fränkische Landesforschung an der Universität Erlangen-Nürnberg. Historische Reihe 13. Neustadt a. d. Aisch.

STIELDORF, A., 2012: Marken und Markgrafen: Studien zur Grenzsicherung durch die fränkisch-deutschen Herrscher. Monumenta Germaniae Historica. Schriften 64. Hannover.

STÖRMER, W., 1999: Franken von der Völkerwanderungszeit bis 1268. Dokumente zur Geschichte von Staat und Gesellschaft in Bayern 2, 1. München.

ŠMILAUER, V., 1960: Osídlení Čech ve světle místních jmen. Praha.

ŠRÁMEK, R., 1999: Úvod do obecné toponomastiky. Brno.

THOMASON, S.-KAUFMAN, T., 1989: Language Contact, Creolization, and Genetic Linguistics. Berkeley.

TRUDGILL, P., 2006: Domains. Introduction. In: The Handbook of Language Variation and Change. Blackwell Handbooks in linguistics (Chambers, J. K.-Trudgill, P.-Schilling-Estes, N., edd.), 473-474. Oxford. 3rd edition.

VAN COETSEM, F., 1988: Loan Phonology and the Two Transfer Types in Language Contact. Dordrecht.

- 2000: A general and unified theory of the transmission process in language contact. Monographien zur Sprachwissenschaft 19. Heidelberg.

WALTHER, H., 1963: Deutsche und slawische Siedlung im oberen Maingebiet, Veröffentlichungen des Instituts für Slawistik der Akademie der Wissenschaften Berlin 29, 95-109.

WIESINGER, P., 1975: Möglichkeiten und Grenzen bei der Erforschung der deutschen Ostsiedlung. In: Die deutsche Ostsiedlung des Mittelalters als Problem der europäischen Geschichte. Reichenau-Vorträge 1970-1972. Vorträge und Forschungen 18 (Schlesinger, E., ed.), 161-192. Sigmaringen.

WINKLER, R., 1999: Bayreuth. Historisches Atlas von Bayern. Franken I, 30. München.

WULF, Ch., 2000: Toponomastik und Sprachkontakt. Eine Untersuchung der slawischen und slawisch-deutschen Toponyme in Schleswig-Holstein. Studien zur Siedlungsgeschichte und Archäologie der Ostseegebiete 2. Kiel.

ZSCHIESCHANG, Ch., 2003: „Das land tuget gar nichts.“ Slaven und Deutsche zwischen Elbe und Dübener Heide aus namenkundlicher Sicht. Namenkundliche Informationen. Beiheft 22. Leipzig.

\section{Zusammenfassung}

Der soziale Kontext des slawisch-deutschen Sprachkontakts. Nordostbayern und das Egerland im Frühmittelalter

\section{Problemformulierung und Lösungsmethoden}

Im Rahmen eines langen geographischen Gürtels, in dem sich im Frühmittelalter deutsche und slawische Dialekte vermischten, sind das heutige nordöstliche Bayern und das Egerland eines der interessantesten Problemgebiete (Klír 2015; im Druck; Abb. 1-2). Die einzigartige Quellenlage erlaubt es dort für das Frühmittelalter, die Beziehung zwischen dem unterschiedlichen Sprachgebrauch, der Herausbildung einer ethnischen Identität und der materiellen Kultur 
zu beobachten. Der hier vorgelegte Beitrag klärt diese Problematik nicht komplex, sondern konzentriert sich auf die sprachlichen Aspekte. Die Hauptfragen lauten: 1) welche sozialen Prozesse führten zum slawisch-deutschen Sprachkontakt und 2) zu welcher Zeit, in welchen Gebieten und in welchen Teilen der Gesellschaft war die slawische oder deutsche Sprache, ggf. beide Sprachen gleichzeitig vertreten. Bei ihrer Klärung machen wir davon Gebrauch, dass das Frühmittelalter die Periode eines Siedlungsvorgangs war und dass die zeitlich und sozial variablen Sprachverhältnisse in der Ausformung toponymischer Systeme ihren Niederschlag fanden, die in den jeweiligen Teilen Nordostbayerns und des Egerlandes auffallend unterschiedlich sind.

Der vorliegende Beitrag ist in zwei Teile untergegliedert. Der erste Teil präsentiert den theoretischen Grundrahmen und basiert auf ausgewählten Modellen der gegenwärtigen Onomastik und Soziolinguistik (Kap. 2-5). Der zweite Teil enthält eine Übersicht, eine Analyse, einen Vergleich und eine Interpretation der einzelnen Toponym-Kategorien in Nordostbayern und im Egerland (Kap. 6-8).

Im Prinzip setzen wir zwei hauptsächliche mögliche Situationen voraus. Zum Ersten war es in Nordostbayern infolge einer Expansion der sozial minoritären slawischen Sprache zum deutsch-slawischen Sprachkontakt gekommen (Immigrationskontext des Sprachkontaktes). Zum Zweiten infolge einer Expansion der sozial dominanten deutschen Sprache (Kontext vom Typ „conquest“"). Im ersten Fall muss mit einer Migration oder einem Transfer der Slawischsprecher gerechnet werden, im zweiten Fall ist ein Migrationsmodell nicht unbedingt erforderlich (Kapitel 3). Kriterium für die Identifikation des sozialen Kontextes des slawisch-deutschen Sprachkontaktes soll eine bestimmte Formel in der Distribution der germanisch-frühdeutschen und slawischen Hydronyme und Ortsnamen sein (Kapitel 5).

Im methodisch angelegten Kapitel 4 wird hervorgehoben, dass uns ein konkretes Toponym nicht über die sprachlichen Verhältnisse in der Gesellschaft als Ganzes informiert. Seine Aussage kann nur einige von vielen sprachlichen Domänen, Personennetzwerken und nur einige der in der Gesellschaft vertretenen sozialen Klassen betreffen. Anders gesagt sind onymische Systeme in Sprachkontaktgebieten ein sozial unausgewogener, aus dem Repertoire der Mitglieder von verschiedenen sozialen Klassen stammender Torso, in dem sich ausgewählte Formen in verschiedenen Sprachdomänen und Personennetzwerken miteinander vermischen. Unsere Aufgabe ist es, dieses System zu dekodieren und zu bestimmen, in welchem Zeitraum, in welcher relativen Aufeinanderfolge und in welchen sozialen Klassen es vertreten war und in welchen Sprachdomänen und Personennetzwerken die slawische oder deutsche Sprache realisiert wurde.

\section{Ergebnisse}

Spätestens ab der zweiten Hälfte des 8. Jahrhunderts ist es in Nordostbayern zum slawisch-deutschen Sprachkontakt gekommen. Kontrastive Unterschiede in Form von toponymischen Systemen, besonders eine divergente räumliche Distribution von slawischen Hydronymen und einfachen und gemischten Ortsnamen deuten an, dass unterschiedliche soziale Prozesse zu diesem Kontakt geführt haben (Abb. 4-5, 7, 9-10, 12). Damit Hand in Hand geht die Aussage der räumlichen Verbreitung von germanisch-frühdeutschen Hydronymen und sog. archaischen Ortsnamen, die auch grobe chronologische Anhaltspunkte liefern (Abb. 4-5, 8, 10, 13). Aus Sicht der soziolinguistischen Klassifizierung gibt es den Anschein, dass es in einem Teil Nordbayerns in einem Immigrationskontext zum Sprachkontakt kam, und im anderen Teil wiederum in einem als „conquest“ bezeichneten sozialen Kontext. Beide Gebiete haben sich, solange es um die Menge der Slawischsprecher geht, nicht radikal voneinander unterscheiden müssen. Der Unterschied konnte auch auf vielen weiteren, nur schwer fassbaren sozialen Faktoren basieren, wie etwas Dauer und Enge des Kontaktes, ggf. ein anderes Maß der wirtschaftlichen Integration und Planmäßigkeit des Siedlungsvorgangs.

Als wesentliche Feststellung kann gelten, dass die germanische und später deutsche Sprache im gesamten Gebiet kontinuierlich präsent war und realisiert wurde, wenn auch in den verschiedenen Teilen der Bevölkerung ungleichmäßig. Im Westen und Süden kann man in al- 
len sozialen Klassen mit ihrer Kontinuität und mit einer Realisierung in allen Sprachdomänen rechnen. Umgekehrt war ihre Realisierung im Norden und Osten, einschließlich des Egerlands, zunächst auf die Sprachdomäne „Fernbeziehungen“, ggf. auch „Macht“ beschränkt (Gebiet slawischer Hydronyme, Abb. 6).

Für die karolingisch-ottonische Zeit zweifeln wir es nicht an, dass die Gemeinschaften, von denen die slawische Sprache bevorzugt wurde, in einen sprachlich und ethnisch heterogenen, teiweise auch planmäßigen Siedlungsvorgang eingebunden waren, der in der Toponymie häufig nur wenige Spuren hinterlassen hat, überwiegend in Form von sprachlich gemischten Ortsnamen. Nichtsdestotrotz hat sich in den Randgebieten des fränkischen Reiches, die sozial und wirtschaftlich schwächer kontrolliert wurden und aus denen gleichzeitig in slawische Sprachgebiete gerichtete Verkehrskorridore herausführten, während des Siedlungsvorgangs eine relativ ausgeprägte und bisweilen auch fast völlig slawische Toponymie herausgebildet, die auch die Hydronymie von Wasserläufen höherer Ordnung umfasste (9.-12. Jhdt.). Theoretisch kann man sich auch vorstellen, dass die slawische Sprache einen höheren sozialen Status hatte und dass die slawische Namensgebung von den fränkischen Eliten respektiert wurde.

Die vorliegende Studie entstand im Rahmen des Forschungsprojekts GPP405/12/P715 - „Dorfsiedlungen in Böhmen während der Umbruchszeit vom Spätmittelalter zur Frühen Neuzeit“ (Postdoktorandenprojekt der Förderagentur der Tschechischen Republik). Für die anregenden Kommentare zum Text danke ich Dr. Wolfgang Janka (Regensburg), prof. Karlheinz Hengst (Chemnitz), Dr. Christian Zschieschang (Leipzig), Dr. Vít Boček (Brno) und Dr. Milan Harvalík (Prag).

Tabellen und Abbildungen stammen, falls nicht anders angegeben, vom Verfasser.

PhDr. Tomáš Klír, Ph.D., Ústav pro archeologii, Filozofická fakulta Univerzity Karlovy v Praze, Náměstí Jana Palacha 2, 11638 Praha 1, Česká republika,tomas.klir@ff.cuni.cz 
